\title{
TEACHING QUALITATIVE RESEARCH ONLINE ${ }^{1}$
}

$10 / 25 / 2017$

\begin{abstract}
Teaching qualitative research in person provides the opportunity for faculty and students to work collaboratively in understanding the principles of qualitative research. However, how does teaching qualitative research online differ?
\end{abstract}

As Sydney Freeman, Jr., Associate Professor in the Adult, Organizational Learning and Leadership program at the University of Idaho's College of Education, did one final review of his syllabus for ED 589 Theoretical Applications \& Design of Qualitative Research, he knew that this was a different approach to teaching qualitative research. Generally, this kind of information was better taught in person where students could have physical interactions with their professor. The material was often quite challenging to teach. However, this structure was different than many qualitative courses taught across the United States are structured. This was not going to be easy.

ED 589 was a course required for the Ph.D. in Education in the College of Education. It did not matter which specialization you were a part of - students were still required to complete nine (9) credit hours of research electives, this course being one of those five options. The course's main objective was to expand on knowledge from ED 574 Survey of Qualitative Research, examining qualitative research designs and the use of theory in qualitative research. Students would be given the tools to be able to conceptualize a research project and develop a peer-reviewed article. This was achieved through:

1. Class Discussions: Throughout the semesters, students were required to complete the weekly readings from the various textbooks required for class. Based on these readings, which related to that week's topic (i.e., methodologies, abstracts, etc.), students were to answer six to eight questions.

2. Individual Research Projects and Presentations: Each student was required to complete eight assignments throughout the semester, starting with an annotated bibliography and ending with a final (collaborative) presentation. The projects were broken up into the components of a peer-reviewed article, including data collection, analysis, methodology, and developing a findings and conclusion section.

Freeman had taught this course before, and while each semester was a success, each semester was also a little different than the last one. It had always been delivered online, but this time he was curious to know what the most effective way to conduct this class online was. He wasn't sure how his students would react to this year's course design, nor was he sure what further changes to the syllabus might be made before

\footnotetext{
${ }^{1}$ Copyright (C) 2017, Sydney Freeman, Jr. \& Steven Bird. This case was prepared for the purpose of class discussion, and not to illustrate the effective or ineffective handling of an administrative situation. Permission is granted to copy and distribute this case for non-commercial purposes, in both printed and electronic formats.
} 
the start of the semester. As he finished his review, he was hopeful that his students would finish the class feeling confident in their understanding of qualitative research.

\section{Background}

The ED 589 course was offered through the College of Education as an online course for graduate students. ED 574 was a prerequisite, as a lot of the material in ED 589 built upon the earlier course. Typically, six (6) to fifteen (15) students enrolled in the course every spring. Important factors that influenced the wholly online design of the course were (1) the nature of the College's graduate degrees and (2) the type of students that enrolled in the graduate degrees within the College.

\section{College of Education Graduate Degrees}

The College of Education at the University of Idaho offered over ten (10) different graduate programs ranging from Special Education to Athletic Training. For those degrees, there were numerous delivery options, including face-to-face, hybrid, and fully online. Most commonly seen were students who were a part of the hybrid or online programs, including the Master of Science in Athletic Training and the Adult, Organizational Learning and Leadership master's degree.

Most, if not all, of the graduate degrees within the College of Education were designed for working professionals, particularly those state employees that worked in the higher education system. Students who were employed and served in departments/offices such as Movement Sciences, Human Resources, and Financial Aid at the university pursued the degrees offered through the College, seeking more skills and knowledge development within their area of expertise. Many of the doctoral programs were designed as either post-professional degrees (e.g., the Doctor of Athletic Training) or to allow work with the student's area of research (e.g., as a Graduate Assistant within that department or office).

\section{Students Enrolled in the Programs}

Because most of the students enrolled in the university's graduate programs were working adults, courses were designed around their schedules. For the Athletic Training students, they have their on-campus summer coursework. However, during the fall and spring times, they were placed within either clinical affiliation sites or their current employment situations, where they complete their clinical residency/experience and education courses. For the Adult/Organizational Learning and Leadership master's program, the coursework was $100 \%$ online, allowing individuals the flexibility to work on their class assignments during lunch breaks, after work, etc. The Ph.D. in Education, no matter the specialization, has a mixture of face-to-face and online courses. If there were face-to-face courses, these were scheduled towards the end of the business day, usually starting at around 4:30 p.m. Pacific Time. If they were online, and they were synchronous or had occasional virtual meetings, those "class times" were scheduled after five o'clock. Most instructors were privy to the students' work schedules, and accommodated their classes accordingly. In the case of ED 589, most of the students were within the Ph.D. in Education, but had fulltime jobs either with the university or within the Pacific Northwest Region of the United States. The course was originally designed as asynchronous through BbLearn, but had moved to include both synchronous and asynchronous methods.

\section{Online Discussions}

According to Cho and Tobias (2016), "discussion in online classes enhances student learning and facilitates social interaction" (p. 124). It creates opportunities for collaboration, for growth, and for understanding the material better through working with other students. Additionally, it "allows each student equal opportunity to participate in and create collective knowledge by sharing and elaborating ideas" (Cho \& 
Tobias, 2016, p. 124). Ideally, students who had engaged in online discussions could think critically and reflectively and could study together instead of alone.

There were multiple benefits to having an online discussion within a class. First, online discussions provided a community of inquiry (Cho \& Tobias, 2016). These were opportunities for students to have an active interaction with their faculty members, allowing for a better learning process and an overall higher satisfaction with the course material. Students developed a better social presence ("the ability ... to identify with the community"), cognitive presence ("ability to construct and validate meaning"), and a teaching presence ("the teacher's ability to design, facilitate, and direct the cognitive and social process to realize

... learning outcomes") (Cho \& Tobias2016, pp. 124-125). Second, students must be able to dedicate their time to participating with the discussion boards and their online community. Assumedly, through the time it took to read the posts, craft a response, and then read other's response, they were actively learning the material (Cho \& Tobias, 2016). Third, the positive relationships and the ability to foster a creative and interactive online community for students contributed to the overall satisfaction with the course and the retention in the course. Discussion boards, the clarity of assignments, and the involvement of the faculty member all contributed to the overall satisfaction and the "perceived learning" of the student (Cho \& Tobias, 2016, p. 126). Fourth, an online course and its discussion were expected to foster an environment that allowed students to enhance their learning. Because of the heavy interactions with other students, the collaborative knowledge sharing and creation, and the sharing of material and perspectives, students were not only satisfied with the course overall, but their achievements within the course were enhanced. This was to mean that a student might, in an online learning environment, achieved a higher passing grade than those who either were not involved as much or were in non-online courses.

While there was little empirical research that demonstrated the above points, there was evidence to support that online discussions "adds to the discussion of distance education methodology" (Cho \& Tobias, 2016, p. 136). According to Cho and Tobias (2016), while their findings were "in a basic course", it should not be extended to all online courses (p. 136). Online learning communities and their discussion boards might still provide the necessary interactions for students and instructors alike, and should be further examined under other research methods (Cho \& Tobias, 2016).

Overall, online discussions should be "decided with the consideration of various factors including teaching philosophy, course content, intended learning outcomes, and learner characteristics" (Cho \& Tobias, 2016, p. 137).

To this end, however, online discussions provided another side to learning in higher education. Students "who are competent analyzers, synthesizers, and evaluators become workers who are better prepared for the work challenges they will face", and this was no different in an online discussion board (Brierton, Wilson, Kistler, Flowers, \& Jones, 2016, p. 14). It was suggested that distance education might be able to further develop and expand students' higher order thinking ability, allowing them to grasp and build various abilities (Brierton, et al., 2016). This was in addition to the positive "social interactions for ... collaborative learning ... for higher education” (Vuopala, Hyvönen, \& Järvelä, 2016, p. 25). Collaborative learning is "grounded in social constructivist learning theory, which emphasizes that learning and knowledge construction is affected by interaction and collaboration" (Vuopala, et al., p. 26). Combined with the ability to process at a higher order or level of thinking, online learning and discussion boards could provide a multitude of benefits for students, even if it was on a case-by-case or class-by-class basis.

However, as society continued to develop and technology advanced, "distance learning is no longer the exception in higher education" as students "take their classes with them on their iPads, their phones, and other electronic devices" (Watts, 2016, p. 23). One of the more concerning elements to online discussions, while positively producing results in social interactions and higher order thinking, was the lack of a face- 
to-face interaction. A computer screen could unfortunately get you only so far. To date, there seemed to be at least two different forms of online discussions and course environments:

1. Synchronous discussions and course environments: These were live, face-to-face discussions or scheduled class times usually hosted by an online learning management system (e.g., BbLearn Collaborate Ultra, Zoom, or Adobe Connect).

2. Asynchronous discussions and course environments: These were pre-recorded or reused videos, or perhaps just readings and posted announcements, built into the course with no live interaction.

\section{Synchronous Discussions}

According to Watts (2016), "synchronous interaction is becoming a more integral part of communication among students and between students and their instructors" (p. 27). As online learning communities grew, and a more synchronous and social environment was needed, learning management systems such as Canvas, Angel, eLearning, and Blackboard were designed to create new ways to stay connected with each other. While there was no research yet that demonstrated an increased benefit in synchronous versus asynchronous, there was a slight correlation in the synchronous interactions and the students' positive view of the course (Watts, 2016). A 'face-to-face' interaction with students, instructors, and a collaborative classroom learning environment could be had, even with an online course. Students were able to feel engaged once more without having to sit inside of a classroom for three or more hours every other day. However, the fact that students were not attending a physical classroom did not mean synchronous discussions were without faults. Personal and professional schedules still challenged the synchronous online learning idea, particularly with conflicting student schedules and meeting times (Watts, 2016).

This aside, there still seemed to be a more positive impact from synchronous discussions and online learning, both from students and the instructors. Given that students were equipped with working cameras and microphones, the individual student was still able to receive visual cues, feedback, and social interactions from classmates and instructor(s) (Watts, 2016).

\section{Asynchronous Discussions}

Asynchronous learning was the original channel for online learning and course content delivery (Watts, 2016). And while "synchronous interaction is playing a larger role ... asynchronous interaction still has its place in distance education" (Watts, 2016, p. 27). While synchronous learning might provide students with a social and engaging atmosphere, the pressures of a physical, face-to-face classroom were still present. With asynchronous interactions, students could go at their own pace, review the material multiple times if needed, and could think about the material at a deeper level than if they were in class (Watts, 2016). When students could think about what they were learning, and could take a moment to breathe, relax, and really focus on their responses, "cognitive engagement with the content" increased, "especially when the content was difficult" (Watts, 2016, p. 27).

Although they were not engaging in synchronous online work and were not a part of an engaging community, students still felt as if they learned "the material and were very satisfied with the asynchronous nature of the course" (Watts, 2016, p. 27). The amount of reflection and thinking that students were able to do before responding to a discussion question, an assignment, or another student was just as powerful as if they were in a live situation.

\section{Combined Synchronous and Asynchronous Discussions}

Often, synchronous and asynchronous discussions and online learning communities could be used together, although there tended to be a bit of frustration on the student's part from these situations (Watts, 
2016). When students had to be a part of a synchronous group discussion, but follow along to a PowerPoint online in an asynchronous fashion, they generally did not feel as connected to the course (Watts, 2016). If students had to engage in both a live discussion, or perhaps watch a video and then log on to a live discussion, they felt less engaged in the material and more like it was a labor for them. To type responses, listen to audio, read a PowerPoint, and be a part of a social interaction could lead to overload.

Another frustration with synchronous and asynchronous combined was the technical difficulties that could ensue: videos cutting in and out, PowerPoints not loading fully, audio cutting in and out. Students found it frustrating when they experienced these and recommended to their instructor more training needed to be offered before starting class (Watts, 2016).

\section{Master Class}

Master classes were "a class by an expert, especially a musician, for exceptional students, usually presented in public or on television" (Friedlander, 2013, para. 1). Simply put, they were unique classes designed to allow a set of students to learn a topic or range of topics from someone in that area of expertise. The content was usually shaped by the expert providing the instruction and could range across many topics, although generally found within the performing arts (Friedlander, 2013).

In situations of teaching online, it was usually best to bring in guest lecturers who were familiar and were experts within the topic for that lesson. Typically, the instructor would be a participant within the class while the lecturers provided their knowledge and experiences with the topic, often time providing more information than was available in the textbook or readings for that week. Engaging in a master class helped students understand the material in a more digestible way, as the expert providing the lecture was savvy to the information and could present it in a way that was comprehensible.

However, not all master classes were designed for online lectures, and there were times in which students and even the lecturer could get off topic. When having someone as a part of your class providing his or her expertise, it was easy for the students to want to ask about their research, what their thoughts were on topics, and derail the lesson for the day. Providing a strict yet flexible guideline for the course, and perhaps utilizing the Socratic method to bring in discussion questions would enhance the overall benefit of having a master class.

\section{Active Learning Environments}

According to Bell (2016), "existing literature acknowledges that university students find courses in research methods difficult and challenging, and students often perform poorly" (p. 285). The course material could be complex, technical, garnering little student interest in the topic, instilling a belief of irrelevancy, and resulting in low student performance (Bell, 2016). And while the mastery of research method courses was one that students within higher education needed to have, there was still an air of dissonance when the thought of taking the course arises.

One way to increase engagement within research method courses and to help increase student achievement rates was to take advantage of an intensive course design and active participation (Bell, 2016). The literature reported that the best intensive course designs were those that were in condensed formats that included evening or work-based programs, enlisted the help of an experienced and positive instructor, provided an active-learning environment, and were built around an overall good course organization (Bell, 2016).

When considering an active learning environment, even one that was online, it was important to remember that students learned best when engaging in the subject matter itself. When students were engaged in the topic, they were able to think about the information, process it, and develop a better understanding of 
the topic or topics. Students who were "more likely to fully engage in learning [and] perceived meaningful reasons for participating in the activity" including "developing an understanding of the activity content and improving or gaining new skills" (Bell, 2016, p. 287). In situations with qualitative research, and particularly with qualitative research online, engaging in activities that allowed students to take the information they read or watched (if on video) actively put them in the situation of applying that information. This could include research design projects, abstracts, peer-reviewed articles, blogs, interviews, etc. Engaging in the subject itself could increase the willingness to learn the material and to help them better understand the topics.

While instructors "use group work and group presentations to engage students", it should also be noted that instructors needed to be supportive in "student ownership of their learning process ... space for reflection and feedback via peer groups" (Bell, 2016, pp. 287-288). This allowed the students to feel the most engaged with their work, while at the same time socially interacting with their online classmates.

\section{ED 589 Design}

The ED 589 course design utilized a mixture of synchronous and asynchronous interactions, master classes, and active learning engagements. Students were required to complete asynchronous discussion boards with their peers, replying to student discussion threads for the weekly readings as assigned. They were also required to complete a set of assignments that would ultimately result in a peer-reviewed article.

\section{Required Weekly Discussions}

During the semester, one or more questions or prompts were posted for the whole class to discuss each week. Freeman predetermined these questions and ensured they were in line with those readings he thought most important. While much of the readings were based on the textbooks, there were occasionally extra readings or resources that Freeman posted.

The discussions were evaluated on three elements:

1. Quality: Messages that added value to the discussion. In short, this meant not a simple "I agree" post. Freeman provided examples that added value to a post. These, included:

a. Students posted an original answer to a question posed by a classmate,

b. Students were expected to indicate whether they agreed or disagreed with what another person posted, and why,

c. Students used the $2 \times 2$ technique (i.e., give 2 instances why you agree with the post and 2 instances why you disagree with the post), or

d. Students related a recent news event, article, or such they had read. They were expected not to simply link to it, but explain the relevance and also come up with a scenario or example of how they might apply the materials.

2. Timeliness: Research and experience showed that students get the most out of an online course by participating in the discussions early and following them as they evolve. Each student had a significant contribution to make to the class, and answers to the questions were welcomed early.

3. Quantity: One of the hardest of the three to address was quantity. Freeman did not want to establish a minimum nor a maximum number of posts as a requirement, and he did not expect the students to answer each of them. But he did encourage the students to answer to at least one or two of the discussion threads and to get involved.

Each discussion was worth a total ten points, with six discussion boards spread out throughout the entire seventeen (17) week course (See Exhibit 1 for an example). 


\section{Required Research Projects}

Freeman wanted the students to feel engaged in qualitative research, especially because they were doctoral students, and they would eventually be engaging in research of their own for their dissertations. As a way to encourage this type of active learning, Freeman established nine (9) assignments based around a peer-reviewed article. More specifically, he broke down the elements of a peer-reviewed article and attempted to address each one in an individualized way. The assignments included:

1. CITI Protecting Human Research Participants Certificate and IRB Protocol: Students were expected to complete an online course that would discuss various aspects of human subject research. After completing the assignment, students would be given a certificate of complete showing that they had taken the CITI exam and were successfully certified. This was in addition to completing the University of Idaho IRB Protocol Submission process for their own research ideas. Freeman provided the information that would be associated with the topic, and they were to complete a full IRB process on that topic.

2. Annotated Bibliography: Students were expected to develop an annotated bibliography on the topic assigned. They were to provide at least fifteen (15) references that could be used in the development of their final paper. However, additional references would be expected in the final paper.

3. Abstract: Students were expected to develop an abstract and to follow their reading's activity on drafting an abstract. Each abstract was assessed by the rubric created by Freeman.

4. Methodology Presentation: In the past, students were the most confused on methodologies for their final papers. As an attempt to fix this, Freeman included a methodology presentation. Students were assigned a research methodology (e.g., case study, grounded theory, ethnography). They were expected to complete a presentation describing the research approach, the origin of the approach, the various types of research designs within the approach, the advantages and challenges of the approach, and how to conduct an analysis to determine the appropriate sample size for the approach.

5. Research Proposal: Students were expected to write a 10 to 12-page research proposal with an introduction, a literature review, and a research design statement.

6. Interview Transcriptions and Demographic Summary Table: Students were expected to conduct five (5) interviews and transcribe each based on the topic that they were assigned. They would also be expected to develop a demographic summary table and a coding summary document (See Exhibit 2 for an example).

7. Findings and Conclusion (Final Paper): Students were expected to synthesize the findings that they collected throughout the semester and describe them in one paper. While the final paper was to be between 20 and 25 pages, excluding references and the title page, the findings and conclusion element were expected to be between 5 and 8 pages (See Exhibit 3 for an example).

8. Presentation: This was a group assignment. The students were required to work along with their colleagues to develop a presentation that summarized their findings and provided recommendations for future policy and practice.

\section{One-on-One Sessions}

Because ED 589 was structured differently than other online classes, Freeman had to develop a way that would still provide a sense of mentorship for the students. ED 589 was primarily meant to provide opportunities for mentoring by a faculty member, in particular the instructor. Freeman designed the course so 
that it was an option for the students to set up one-on-one sessions with him, that way he could meet with the students, talk to them about their progress, and provide feedback when necessary.

These sessions were administered through either BbLearn Collaborate Ultra or Zoom, whichever worked better for the course and the purpose of the one-on-ones.

\section{Master Classes}

Freeman wanted students to engage with the topics and to be able to understand them as well as he had. To this end, he decided to incorporate master classes into the design of the course. When organizing the master classes for ED 589, Freeman wanted to provide both his students and the guests with the best experience possible. As he began to identify which topics would have a master class associated with them, he thought it best to reach out to the individuals to gauge interest, organize a suitable time and day, as well as provide them with the information about the students' projects. This way, when the individuals came to class, they would have a better understanding of what was expected of the students and their projects. Freeman wanted to give the individuals the ability to talk specifically about their area of expertise, when they arrived online. With an hour-long class, he had to be careful the amount of time this took thirty minutes sounded reasonable. The guests would be able to talk about their areas, how they approached their research, give examples, and then answer any questions that students might have. Following that, Freeman wanted to have the guests provide feedback on the students' individual projects: what could they do to improve their projects and make them stronger? How could the individual's expertise influence how the students approached their projects? Based on conversations with students during class, as well as any information that Freeman provided the guests prior to class, the students would receive constructive feedback on how to enhance their research projects.

As he put more thought into whom he would invite, Freeman decided it best to bring in Dr. Dan Campbell from the University of Idaho, Dr. Claire Major, author of one of their textbooks, and Dr. Pam Bettis from Washington State University and author of a chapter in another textbook used within the course. He wanted each of them to provide their area of expertise and allow the students the chance to learn from those within the field.

Dr. Campbell provided insight regarding how to use Qualtrics, coding within qualitative research, and the beginnings of data analysis within qualitative research (See Exhibit 4 for an example). He would be able to give the students a better understanding of the basic functions of Qualtrics, what it looks like to code within the program, and tips and techniques for easier times with coding. While bringing in Dr. Campbell would be a live, synchronous event for the course, this did not exclude the opportunity for students who could not attend to work with Dr. Campbell at a later date. Freeman would encourage his students to work with Dr. Campbell outside of class to continue to gain greater understanding of the concepts of data analysis, coding, and Qualtrics. He was available for questions from students who wanted additional information, needed more resources, or perhaps did not understand a concept discussed in class.

As for Dr. Major, she would provide insight into qualitative research as a whole. As author of Qualitative Inquiry: The essential guide to theory and practice, Dr. Major's thoughts and opinions on the students' work, as well as her advice for the remainder of the semester, would lead the students in the right direction for being able to complete their final papers.

Dr. Bettis would provide clarification on using multiple theoretical and conceptual frameworks in studies on organizational change and identity. Students would benefit from having the opportunity to ask questions about theoretical and conceptual frameworks, gaining a better understanding of those concepts. They would also have a better understanding of how to apply theoretical and conceptual frameworks in qualitative studies. 


\section{Quality Matters}

Quality Matters is an internationally recognized set of standards for online courses that the Distance and Extend Education department at the University of Idaho has endorsed and encouraged faculty to incorporate in their course design. The Quality Matters standards for a successful online course were 1) course overview and introduction, 2) learning objectives, 3) assessment and measurement, 4) instructional materials, 5) course activities and learner interactions, 6) course technology, 7) learner support, and 8) accessibility and usability. Each standard should be met and should be kept in mind when designing an online course. These standards could be used as guidelines and resources for the development of online courses in higher education (See Exhibit 5 for an example).

\section{ED 589 Grading and Design Issues}

Freeman designed ED 589 to equal a total of 1300 points. Some assignments were weighted more than others. Because of their importance, they had to be treated as such. The breakdown was:

\begin{tabular}{|l|c|}
\hline Assignment & Points Possible \\
\hline Class Introduction & 50 \\
\hline CITI certificate & 30 \\
\hline IRB Protocol Assignment & 100 \\
\hline Discussion & 60 \\
\hline Annotated Bibliography & 50 \\
\hline Abstract Proposal & 50 \\
\hline Methodology Presentation & 60 \\
\hline Article Proposal & 250 \\
\hline Interview Transcriptions/Description Table & 250 \\
\hline Final Paper & 250 \\
\hline Final Presentation & 50 \\
\hline Total & $1300 \mathrm{pts}$ \\
\hline
\end{tabular}

\section{Technology Issues}

Collaborate, a video conferencing platform provided through the learning management system BbLearn for educational purposes, was the original method of synchronous delivery within the class. In the beginning, BbLearn Collaborate was used; however, several technical issues occurred from semester to semester. Freeman worked with the Distance and Extended Education department at the University Idaho, exploring a new version of Collaborate, BbLearn Collaborate Ultra. Ideally, Collaborate Ultra would run smoother than the original Collaborate, but time would tell. Collaborate Ultra and the original Collaborate had never been entirely user-friendly, although BbLearn in general was.

After the first video session, Freeman decided to explore other options for synchronous meetings. With additional support from university administrators, Freeman chose Zoom as his method for video sessions. This was free for individuals throughout the university and worked in the same way as Adobe Connect and Collaborate. Zoom, however, was designed to be more functional (See Exhibit 6 for an example).

While technology could be a frustrating experience for both instructors and students, Freeman was confident that his solution was the best. He would utilize BbLearn for grades, assignments, and posting content. Students were familiar with the platform, and it worked seamlessly. For video sessions, if Collabo- 
rate Ultra was not an option, he would continue to utilize Zoom. The recorded sessions, no matter the platform, would be uploaded to YouTube at the end of the session, available for students to review if needed.

\section{Deadlines}

Freeman wanted to be able to post a schedule on the syllabus that seemed to work best with the type of students who were enrolling in the course. Therefore, he removed exact dates and included only the week that assignments were due. Instead of saying that an assignment would be due on January $11^{\text {th }}$ at 11:59 p.m., the schedule would say that it would be due the Sunday of Week 1 at the same time.

Freeman made it clear that the weeks began on Monday and ended on the following Sunday. Students should not have had any issue understanding that element of the syllabus. Should they?

A mistake made too often by students was to overlook even the simplest of details, including the dates and deadlines of projects. For some, it could be that they legitimately counted the weeks wrong, and then once they were towards the end of the semester, they were two weeks off. Dates might provide a safer guideline for students, especially working individuals who need that reassurance that they on the right track, and that a deadline was when they thought it was going to be. There was nothing more panicinducing in the class than realizing the students' major assignment was due one week earlier than they thought.

\section{Attendance for Synchronous Classes and Master Classes}

While attendance was not mandatory for Freeman, it was important to be a part of class. He didn't take attendance, but being an active participant in the discussions was what helped students the most, especially during the master classes, where guest lecturers came and took time out of their schedules to provide insights for the students.

However, how could he ensure that students come without feeling obligated to be a part of an online course? How could he navigate the schedules of those students who might not be able to come, or who forgot? Perhaps they were stuck in traffic, or perhaps they were working late? An issue that Freeman had frequently run into in the past was students not attending their live class. And while Freeman did record each class, it did not help the student who might have multiple questions better suited for the discussion on that day. Or, perhaps, there were elements that just could not be explained, or gathered from a recorded lecture.

\section{Finalizing the Course Syllabus}

Overall, the syllabus seemed to fit Freeman's expectations for the course objectives (See Exhibit 7). Of course, there were always going to be areas of improvement, but those were learning curves for both him and his students. As doctoral students, they were generally flexible and understanding about any changes that arose during the course. Some critical considerations were:

- Should there be more in-depth conversations happening on the discussion boards? Were the questions that Freeman had developed enough to engage his students in a thought-provoking way? What questions would help Freeman in this situation, particularly where the concepts seemed better fit for active learning?

- Should he invite guest lecturers/experts in qualitative research to reinforce understanding of various critical concepts? While the idea of a master class was rooted in music, the concept could be 
applied other courses. What did Freeman need to look for in a guest lecturer, and how should he structure those particular class sessions?

- Should the course be primarily asynchronous, or should he make the course more synchronous and attendance during those times mandatory? Freeman did not want to make the class sessions mandatory, as he understood his student population. However, did students learn better in fully asynchronous classes, fully synchronous, or a mix? While he tried a mixture of both, perhaps he needed to evaluate further what kind of class sessions he facilitated.

- How could he better help the students in learning the materials online? Master classes and discussion boards could only go so far, and Freeman also helped his students outside in one-on-ones sessions. What were other techniques for helping students master the course material?

- Should he provide a more detailed course schedule, and what should that look like? Freeman tried to include dates, and in this iteration of the course he tried to only include weeks without its associated dates. Both approaches left Freeman with tension from both sides.

- How could he introduce the concepts of data analysis and the defining conceptual and theoretical frameworks in the most effective ways? How could he reinforce the different methodologies within qualitative research? Too often Freeman found that the most complex topics in qualitative research were either not mastered satisfactorily, or that students just were not actively engaged in the material. Guest lecturers only reinforced the concepts covered previously in the course. But they were not responsible for ensuring that students mastered the concepts. How could he ensure that the topics he covered were being utilized effectively and that the students were able to take the concepts and work them into their own projects?

While Freeman had taught this course before, he was sure that this time around would not be like the other times. He completely readjusted how the syllabus looked, adding elements and adjusting the material to better fit what he thought that students would need to know and appreciate. He wanted to make sure that the students got the most out of what they came for. The master classes would be a perfect addition to helping the students understand certain concepts, and the flexibility in the deadlines would be easier for students to understand. Perhaps he made it too easy for them, but then again, it was his course. The goal was for students to learn, and to increase mastery of the concepts related to qualitative research. 


\section{Exhibit 1: Discussion Boards}

The main discussion board page.

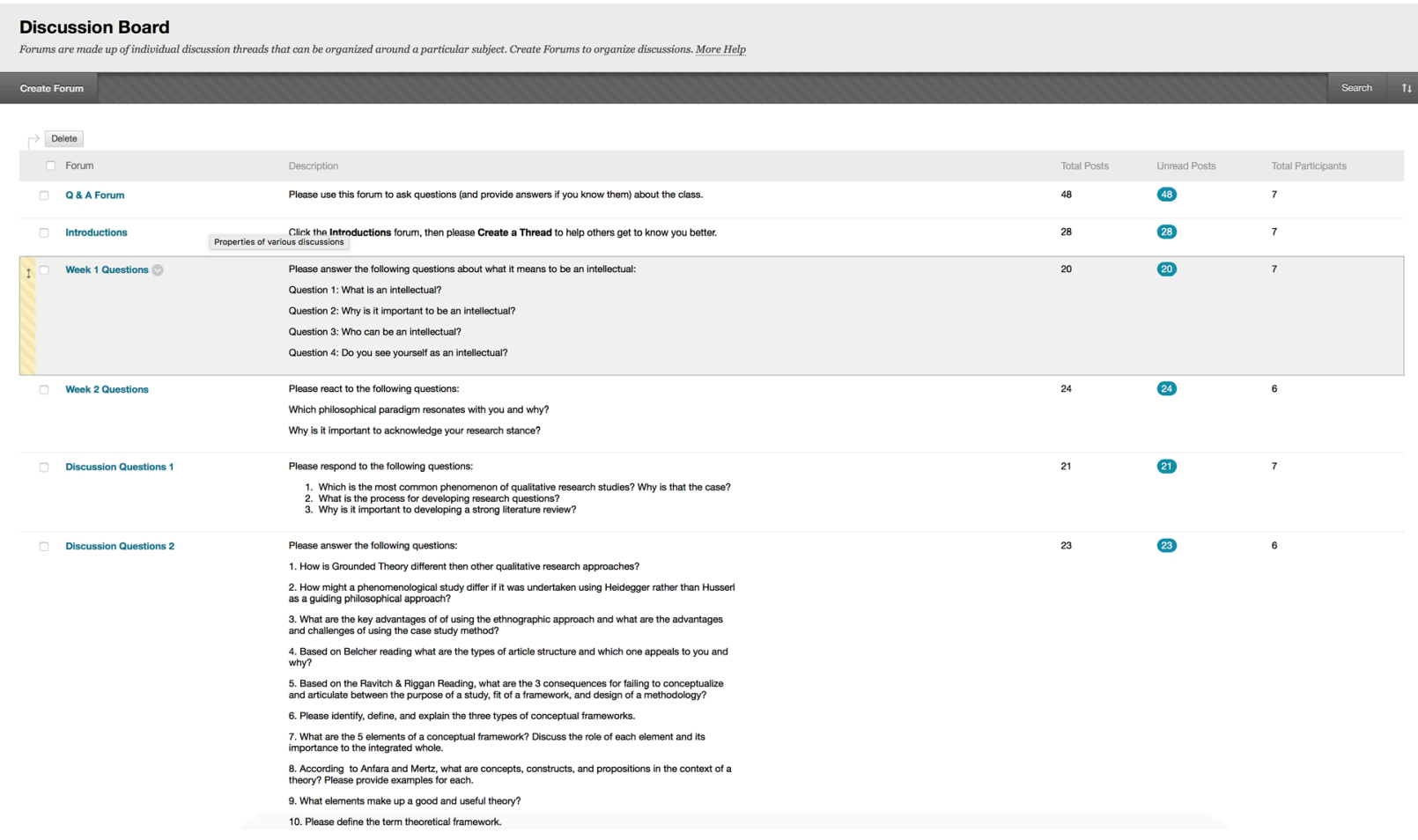

Top level discussion forum for each question.

Forum: Discussion Questions 2

Organize Forum Threads on this page and apply settings to several or all threads. Threads are listed in a tabular format. The Threads can be sorted by clicking the column title or the caret at the top of each column. More Help Groatio Thread Grado Discussion Forum Subscribo

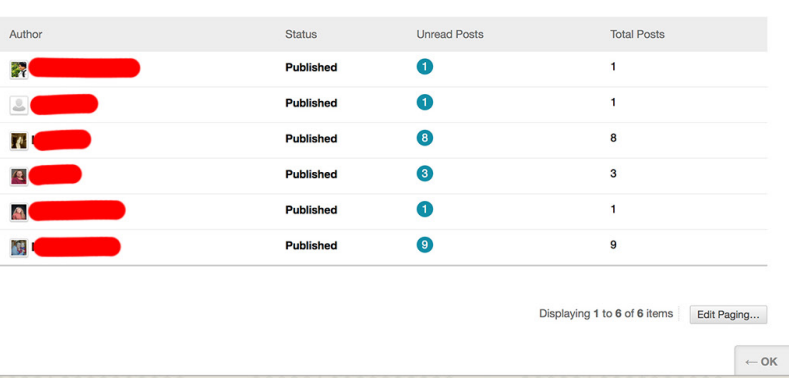


Discussion thread for each response.

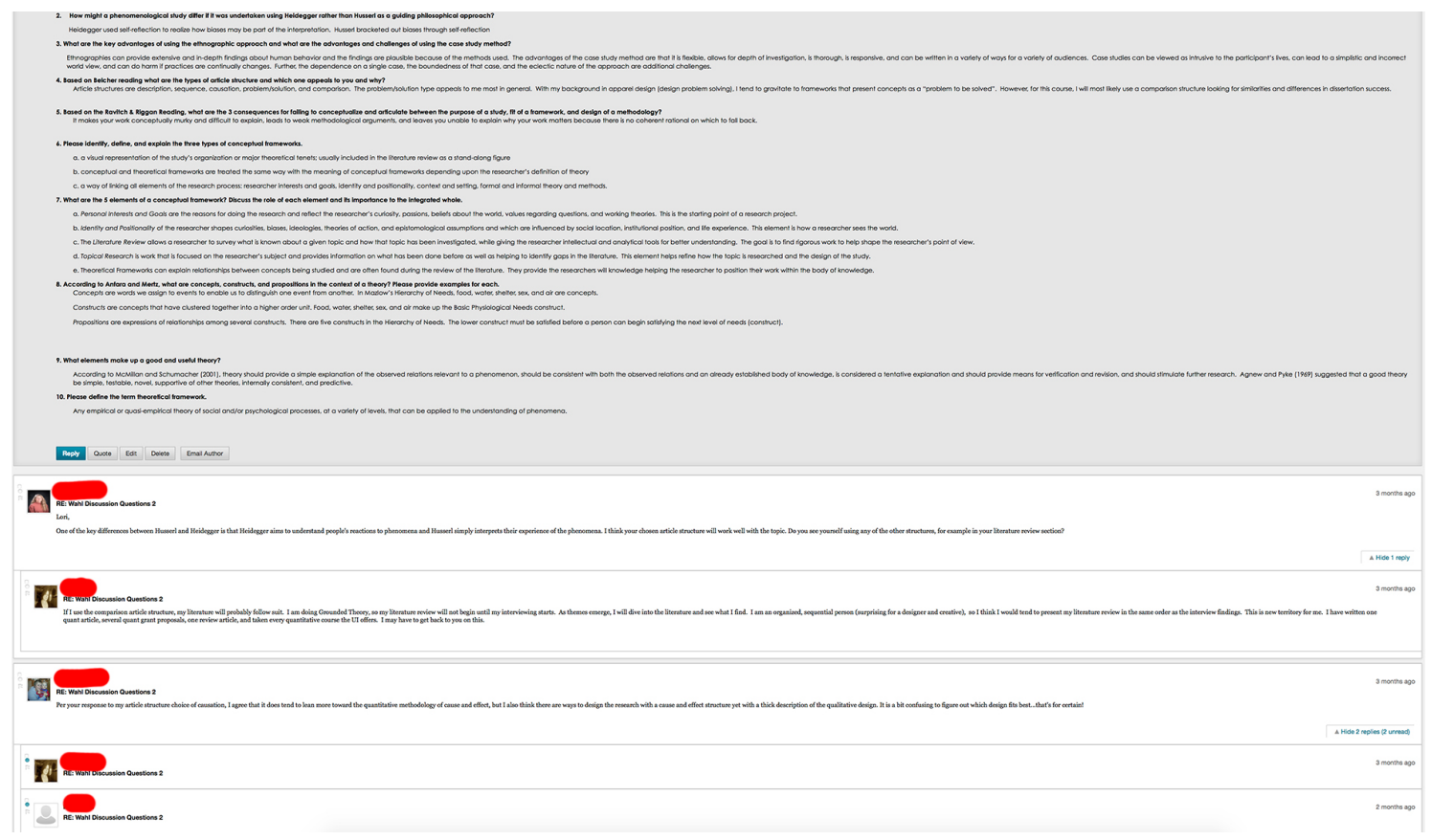




\section{Exhibit 2: *Coding Summary Table (Interview Assignment)}

How did you choose your dissertation committee?

\begin{tabular}{|l|l|l|l|l|l|}
\hline Emergent Codes & Heather & Jim & Catherine & Sharon & Grace \\
\hline $\begin{array}{l}\text { Foundational } \\
\text { Knowledge }\end{array}$ & $\mathrm{X}$ & & $\mathrm{X}$ & & \\
\hline Knowledge Discovery & $\mathrm{X}$ & & & & $\mathrm{X}$ \\
\hline $\begin{array}{l}\text { Participant Committee } \\
\text { Choice }\end{array}$ & $\mathrm{X}$ & $\mathrm{X}$ & $\mathrm{X}$ & $\mathrm{X}$ & $\mathrm{X}$ \\
\hline $\begin{array}{l}\text { Major Professor Com- } \\
\text { mittee Choice }\end{array}$ & $\mathrm{X}$ & $\mathrm{X}$ & $\mathrm{X}$ & $\mathrm{X}$ & \\
\hline Personal Attributes & $\mathrm{X}$ & $\mathrm{X}$ & $\mathrm{X}$ & & \\
\hline $\begin{array}{l}\text { Consequences of } \\
\text { Availability }\end{array}$ & $\mathrm{X}$ & $\mathrm{X}$ & & & \\
\hline
\end{tabular}

How influential was your dissertation committee chair in the development of your dissertation? What did they specifically do to help you throughout the process?

\begin{tabular}{|l|l|l|l|l|l|}
\hline Emergent Codes & Heather & Jim & Catherine & Sharon & Grace \\
\hline Limited Aide & & $\mathrm{X}$ & & & $\mathrm{X}$ \\
\hline Lack of Knowledge of Topic Area & $\mathrm{X}$ & $\mathrm{X}$ & & $\mathrm{X}$ & \\
\hline Self-Motivation & $\mathrm{X}$ & & & $\mathrm{X}$ & \\
\hline Self-Directed & & & & $\mathrm{X}$ & \\
\hline Lack of Working Relationships & & $\mathrm{X}$ & $\mathrm{X}$ & & \\
\hline Self-Doubt & $\mathrm{X}$ & $\mathrm{X}$ & & & \\
\hline Influence of Major Professor & $\mathrm{X}$ & $\mathrm{X}$ & $\mathrm{X}$ & & \\
\hline Communication Issues & $\mathrm{X}$ & & $\mathrm{X}$ & & \\
\hline $\begin{array}{l}\text { Knowledge Base of Major Profes- } \\
\text { sor }\end{array}$ & $\mathrm{X}$ & $\mathrm{X}$ & $\mathrm{X}$ & & \\
\hline Experiential Learning & $\mathrm{X}$ & & & & \\
\hline
\end{tabular}

What was the topic of your dissertation? And how did you choose it?

\begin{tabular}{|l|l|l|l|l|l|}
\hline Emergent Codes & Heather & Jim & Catherine & Sharon & Grace \\
\hline Relevancy & & & X & & X \\
\hline $\begin{array}{l}\text { Personal } \\
\text { Choice/Motivation/Eth } \\
\text { ics }\end{array}$ & X & & X & X & \\
\hline Instructor Influence & & & X & X & \\
\hline Lived Experiences & & X & X & & \\
\hline Knowledge Discovery & & X & X & & \\
\hline Self-Doubt & & X & & & \\
\hline
\end{tabular}


What research methodology/approach did you utilize? What made you choose this approach?

\begin{tabular}{|l|l|l|l|l|l|}
\hline Emergent Codes & Heather & Jim & Catherine & Sharon & Grace \\
\hline Relevancy & & & X & & X \\
\hline Instructor Influence & & X & & X & \\
\hline Personal Interest & $\mathrm{X}$ & & & X & \\
\hline Knowledge Discovery & $\mathrm{X}$ & $\mathrm{X}$ & $\mathrm{X}$ & & \\
\hline Narrative & $\mathrm{X}$ & $\mathrm{X}$ & $\mathrm{X}$ & $\mathrm{X}$ & $\mathrm{X}$ \\
\hline Self-Doubt & & $\mathrm{X}$ & & & \\
\hline $\begin{array}{l}\text { Lack of Knowledge } \\
\text { Base }\end{array}$ & & $\mathrm{X}$ & & & \\
\hline Research Conflicts & & & $\mathrm{X}$ & & \\
\hline
\end{tabular}

What was the overarching theory/theories that framed your study? Were there specific reasons you were drawn to this/these theories?

\begin{tabular}{|l|l|l|l|l|l|}
\hline Emergent Codes & Heather & Jim & Catherine & Sharon & Grace \\
\hline Knowledge Discovery & $\mathrm{X}$ & $\mathrm{X}$ & & & $\mathrm{X}$ \\
\hline $\begin{array}{l}\text { Personal Inter- } \\
\text { est/Beliefs/Ethics }\end{array}$ & $\mathrm{X}$ & & & $\mathrm{X}$ & \\
\hline Personal Relationships & & & & $\mathrm{X}$ & \\
\hline Relevancy & & $\mathrm{X}$ & & & \\
\hline $\begin{array}{l}\text { Foundational } \\
\text { Knowledge }\end{array}$ & $\mathrm{X}$ & & $\mathrm{X}$ & & \\
\hline Framework of Study & & & $\mathrm{X}$ & & \\
\hline
\end{tabular}

Please describe how you choose your sample(s), your basic data collection, and how you choose to analyze your data?

\begin{tabular}{|l|l|l|l|l|l|}
\hline Emergent Codes & Heather & Jim & Catherine & Sharon & Grace \\
\hline $\begin{array}{l}\text { Based on Research } \\
\text { Design }\end{array}$ & & & & $\mathrm{X}$ & $\mathrm{X}$ \\
\hline Existing Relationships & $\mathrm{X}$ & $\mathrm{X}$ & $\mathrm{X}$ & & \\
\hline $\begin{array}{l}\text { Similar Lived Experi- } \\
\text { ences }\end{array}$ & $\mathrm{X}$ & $\mathrm{X}$ & & & \\
\hline Committee Influenced & & $\mathrm{X}$ & & & \\
\hline Self-Doubt & & $\mathrm{X}$ & & & \\
\hline Knowledge Discovery & & $\mathrm{X}$ & $\mathrm{X}$ & & \\
\hline $\begin{array}{l}\text { Self- } \\
\text { Motivated/Learned }\end{array}$ & & $\mathrm{X}$ & & & \\
\hline Bias in Data Analysis & $\mathrm{X}$ & $\mathrm{X}$ & $\mathrm{X}$ & & \\
\hline $\begin{array}{l}\text { Foundational } \\
\text { Knowledge }\end{array}$ & & & $\mathrm{X}$ & & \\
\hline
\end{tabular}


After completing your study, would you go back and change any part of how you conducted your research?

\begin{tabular}{|l|l|l|l|l|l|}
\hline Emergent Codes & Heather & Jim & Catherine & Sharon & Grace \\
\hline $\begin{array}{l}\text { Over-Collection of } \\
\text { Data }\end{array}$ & & & $\mathrm{X}$ & & $\mathrm{X}$ \\
\hline Self-Taught & & $\mathrm{X}$ & & $\mathrm{X}$ & \\
\hline Self-Motivated & $\mathrm{X}$ & $\mathrm{X}$ & & $\mathrm{X}$ & \\
\hline $\begin{array}{l}\text { Non-Supportive Com- } \\
\text { mittee }\end{array}$ & & & & $\mathrm{X}$ & \\
\hline $\begin{array}{l}\text { Foundational } \\
\text { Knowledge of Major } \\
\text { Professor Important }\end{array}$ & & & & $\mathrm{X}$ & \\
\hline $\begin{array}{l}\text { Lack of Direc- } \\
\text { tion/Support }\end{array}$ & & $\mathrm{X}$ & & & \\
\hline $\begin{array}{l}\text { Consequence of Study } \\
\text { Choice }\end{array}$ & & $\mathrm{X}$ & $\mathrm{X}$ & & \\
\hline Self-Doubt & $\mathrm{X}$ & $\mathrm{X}$ & $\mathrm{X}$ & & \\
\hline
\end{tabular}

What do you think made your dissertation stand out and why?

\begin{tabular}{|l|l|l|l|l|l|}
\hline Emergent Codes & Heather & Jim & Catherine & Sharon & Grace \\
\hline Validity High & & & & & X \\
\hline Self-Motivated & $\mathrm{X}$ & & & $\mathrm{X}$ & \\
\hline Lack of Direction & & $\mathrm{X}$ & & & \\
\hline $\begin{array}{l}\text { Foundational } \\
\text { Knowledge }\end{array}$ & & $\mathrm{X}$ & & & \\
\hline Committee Knowledge & & $\mathrm{X}$ & & & \\
\hline $\begin{array}{l}\text { Major Professor } \\
\text { Knowledge }\end{array}$ & & $\mathrm{X}$ & & $\mathrm{X}$ & \\
\hline Relevancy of Topic & & & $\mathrm{X}$ & & \\
\hline Passion of Topic & $\mathrm{X}$ & & $\mathrm{X}$ & & \\
\hline Knowledge Discovery & $\mathrm{X}$ & & & & \\
\hline
\end{tabular}

What do you or did you plan to do with the information that came from your dissertation (ie. Turn it into a book, article, etc.)?

\begin{tabular}{|l|l|l|l|l|l|}
\hline Emergent Codes & Heather & Jim & Catherine & Sharon & Grace \\
\hline Journal Article & & $\mathrm{X}$ & & & $\mathrm{X}$ \\
\hline $\begin{array}{l}\text { Adds to Knowledge } \\
\text { Base }\end{array}$ & & $\mathrm{X}$ & & $\mathrm{X}$ & \\
\hline $\begin{array}{l}\text { Professional Ad- } \\
\text { vancement }\end{array}$ & $\mathrm{X}$ & & & & \\
\hline
\end{tabular}


Is there anything that I should have asked but didn't?

\begin{tabular}{|l|l|l|l|l|l|}
\hline Emergent Codes & Heather & Jim & Catherine & Sharon & Grace \\
\hline $\begin{array}{l}\text { Lack of Training in } \\
\text { Coding }\end{array}$ & & & & & $\mathrm{X}$ \\
\hline $\begin{array}{l}\text { Foundational } \\
\text { Knowledge Important }\end{array}$ & $\mathrm{X}$ & & & & $\mathrm{X}$ \\
\hline Define Bias & & & & & $\mathrm{X}$ \\
\hline Clear Strategy & & & & & $\mathrm{X}$ \\
\hline $\begin{array}{l}\text { Experiential Learning } \\
\text { Important }\end{array}$ & & & & $\mathrm{X}$ & \\
\hline Self-Discovery & $\mathrm{X}$ & $\mathrm{X}$ & & & \\
\hline $\begin{array}{l}\text { Personal Relationships } \\
\text { Important }\end{array}$ & & $\mathrm{X}$ & & & \\
\hline Timeline Important & & & $\mathrm{X}$ & & \\
\hline $\begin{array}{l}\text { Learn Through Confu- } \\
\text { sion }\end{array}$ & $\mathrm{X}$ & & & & \\
\hline Tell a Story & $\mathrm{X}$ & $\mathrm{X}$ & $\mathrm{X}$ & $\mathrm{X}$ & $\mathrm{X}$ \\
\hline
\end{tabular}

*Content written by Lori Wahl and included with permission 


\section{Exhibit 3: *Findings and Conclusion Assignment}

\section{Theoretical Framework}

The purpose of this research is to propose a theoretical model based upon constructs perceived by participants as being helpful or even critical to their success. Participants were asked general questions about their discipline, topic, committee, and cohort. The remaining questions focused on the participant's dissertation with specific questions on capabilities and engagement. The resulting themes are not tied to any particular phase of the doctoral journey, but rather are constants throughout the process. Two intrinsic themes came from within the doctoral student (persistence and passion) while a third theme comes from the student's human relationships.

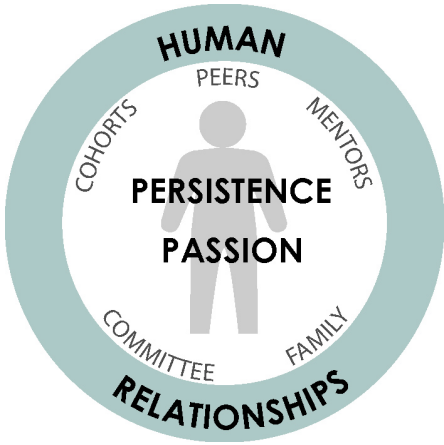

\section{Results}

Three clear themes emerged from the findings: persistence, human relationships, and passion for the topic. Although these themes are consistent for each participant and are interrelated, they are presented as individual theoretical propositions in this paper. These contextual themes are often grouped together in the literature under the phenomenon of doctoral persistence (Spaulding \& Rockinson-Szapkiw, 2012) (Rockinson-Szapkiw, Spaulding, \& Spaulding, 2016). Researchers have described personal factors (motivations, reasons, and strategies), social factors (support and coping systems), and institutional factors (program attributes) as interacting and contributing to students' doctoral persistence (Spaulding \& Rockinson-Szapkiw, 2012). However, minimal attention has been paid to the moment when persistence is tested and the student chooses to continue described as the "breaking point" in this study. 


\begin{tabular}{|l|l|l|l|l|l|}
\hline Emergent Codes & P1 & P2 & P3 & P4 & P5 \\
\hline Independent/Self-starter/Responsibility of Grad Student & $\mathrm{x}$ & $\mathrm{x}$ & $\mathrm{x}$ & $\mathrm{x}$ & $\mathrm{x}$ \\
\hline Commitment to Finish & $\mathrm{x}$ & $\mathrm{x}$ & $\mathrm{x}$ & $\mathrm{x}$ & $\mathrm{x}$ \\
\hline Decision Moment & & $\mathrm{x}$ & $\mathrm{x}$ & $\mathrm{x}$ & $\mathrm{x}$ \\
\hline Surviving the Breaking Point & $\mathrm{x}$ & $\mathrm{x}$ & & $\mathrm{x}$ & $*$ \\
\hline Family Support & & $\mathrm{x}$ & $\mathrm{x}$ & $\mathrm{x}$ & $\mathrm{x}$ \\
\hline Mentor Types & & $\mathrm{x}$ & & $\mathrm{x}$ & $\mathrm{x}$ \\
\hline Graduate Student Friendships & $\mathrm{x}$ & & & $\mathrm{x}$ & $\mathrm{x}$ \\
\hline Not involved in committee selection & & $\mathrm{x}$ & & $\mathrm{x}$ & $\mathrm{x}$ \\
\hline Involved in Committee Selection & $*$ & $\mathrm{x}$ & $\mathrm{x}$ & $\mathrm{x}$ & $\mathrm{x}$ \\
\hline Passion/Interests/Working in the Area & $\mathrm{x}$ & $\mathrm{x}$ & $\mathrm{x}$ & $\mathrm{x}$ & $\mathrm{x}$ \\
\hline PhD Part of Personal Goals & $*$ & $*$ & $\mathrm{x}$ & $\mathrm{x}$ & $\mathrm{x}$ \\
\hline Applying Knowledge Content & & $\mathrm{x}$ & & $\mathrm{x}$ & $\mathrm{x}$ \\
\hline Journey Process & &
\end{tabular}

*= inferred from interview; colors represent code groupings for each theme

\section{Theoretical Propositions for the Completion of a High-quality Dissertation}

\section{Theoretical Proposition 1: Persistence}

The first proposition is that doctoral students' persistence may be tested at a critical breaking point, and the student, mentors, committee, and family need to be prepared and anticipate what support may be needed. The breaking point and the following decision to remain committed to completing the dissertation or leaving will impact attrition.

Although all participants explained their commitment to finish their $\mathrm{PhD}$ programs when they began, four participants in this study described a particular decision moment when they consciously made the decision to continue even though they felt like quitting.

When I finally decided, okay I'm going to pay for fulltime enrollment and go full bore on my dissertation and get it finished, that was probably when I thought, 'Do I really want to do this?' [and] I did.

Another participant recalled the events and her feelings surrounding this particular moment including the argument she had with herself.

I remember, one night, I had just dropped my kids off [at my mom's house]. My youngest was about 2 years old. My husband was teaching that night, and I just felt really guilty... I thought, I don't drop classes unless I accidentally signed up for the wrong one. I just kind of always been like... like a dog with a bone. I just keep going. And I remember thinking "I am burned out, and I am done. I am just tired of doing this. And tonight, I should be taking my kids to the park and doing a picnic, and instead I am doing this." 
And [it] was a selfish kind of all about me thing too. Because I knew that I didn't necessarily want to do something with my doctorate, I just wanted to have it. Anyway, I remember standing in the parking lot thinking, "I'm going to drop this class," and then I was like, 'No, I'm not. I'm going to finish. I finish what I start. And I'm not going to remake this decision again. So, right now I am making a decision to complete no matter what and I'm not going to remake this decision."

One had convinced herself, prior to beginning her dissertation, that she did not and would not hit a breaking point:

I was like, 'Oh no, I'm going to be fine. I won't get a breaking point. I won't get to a point where I'm like-I'm done, I'm done. I don't want to do this anymore'... and I did, and I was surprised, because I was like, "Wait a minute... I don't hit breaking points."

The expression on her face as she was relating this part of her journey was that of bemusement as she recalled this unexpected test of her persistence and resilience. Her commitment to completing the PhD was so strong, that she had never considered navigating a breaking point as she firmly believed that she did not nor would ever come to a point where she needed to consciously decide to continue.

\section{Theoretical Proposition 2: Human Relationships}

The second theoretical proposition is that the academic departments administering Ph.D. programs must encourage support through all kinds of human relationships and monitor student support access from sources other than the major professor and committee. This includes offering education for families to help them understand the level of commitment that a doctoral program of study demands.

Support offered through family, mentors and peers was mentioned by all participants. Four participants specifically mentioned family and the critical role that family played in their success. One participant described his family's involvement as covering events that he needed to miss in order to complete his dissertation:

And I didn't finish alone. My family was supporting me, my parents, my wife, my kids, a lot, I mean, you have to have that support network. My family was able to just step up and say, "You know what? You need to finish this. Because you started it, you need to finish it. It's your project, and we'll cover for you... for years"

Another stated:

I had a good support system... I had an amazing family. You know, my husband's awesome, and he supported me and that part was huge. So, I think having that support around you is good.

A successful mentor support keeps the doctoral student steadily moving toward the completion of the dissertation. One participant described the role of a mentor thus: 
... reminding me that this was my product, my dissertation, my scholarship. His role was not to get me finished. His role was to help me finish. And that was an important distinction.

Another participant also echoed the undertone of mentor as guide and the doctoral student as driver:

[Y] our chair is foundational to helping you work through your research, but I didn't have a reliance on her. I went in knowing what I wanted to study, not the research question, but I knew the area I wanted to study. I knew my particular focus. I knew how I wanted to mesh it. It was more about her assisting me, and the rest of my committee members [assisting me] but her assisting me to guide and finalize and polish that research question and then working through the methodology. I really think that the responsibility lies on the graduate student. I think you are doing a disservice if you think your major professor is the one to carry you in a doctoral program

Support in the form of a cohort or peer offers a different kind of human support from family or mentor. One participant's description of cohort importance demonstrates the profound impact of the cohort on student success:

Extremely influential beyond any measurable sense that I could write, document or say. Had it not been for that cohort,... not only would I have not finished my program, I wouldn't have even stayed at the university.

Another participant recalled several adventures she and her cohort had as they would commute to the university center each evening:

[Cohort members] were really supportive. We had to each bring dinner and actually this is really... totally off the wall, but we each had to bring dinner one night....ah... when we traveled to courses in Boise. My credit card got denied, and then the guy and I found out later that they had sent us new debit cards and neither of us had activated them. And anyway, we were putting all of our pennies together in order for us to get a little dinner that night, so they were great support and we had many great conversations.

There was a great deal of laughing as this participant described the logistics of ending a full day of work and the driving to the campus to take courses at night. She perceived her peers as key facilitators in regular course attendance while at the same time enjoying their company and the support they offered.

\section{Theoretical Proposition 3: Passion for the Topic, Not Passion for the Ph.D.}

The final proposition is for doctoral programs to stress the importance of passion for a topic prior to enrollment in a Ph.D. program clearly explaining to the student how this intrinsic passion will drive the student through the dissertation process. Regular checking is needed during the progression of study to ensure the student is still engaged and interested in the topic.

All participants described obtainment of a Ph.D. as part of their personal goals or for personal satisfaction, and all had strong passions for their areas of research regardless of it being 
tied to a terminal degree. For two participants, the Ph.D. did or will enhance their career path, but four participants clearly explained wanting to take the doctoral journey for personal knowledge gain either to deepen their understanding of a topic or to understand how to approach research to "unlock" information. One participant described his reasons for pursuing doctoral level knowledge as:

I wanted it to be more than words on paper. I wanted it to have meaning and depth. Its not about talking posh, its about understanding how constructs overlay and intertwine to form ideas, and ideas become missions, and missions become goals, and goals become reality.

Some participants mentioned the practical application of the scholarship obtained during the dissertation process, and their excitement at being able to apply this knowledge. One participant was an administrator at a junior high school, and her passion was working with kids and their families. Her reasons for the pursuit of the doctoral degree were not for the degree itself, but for the information that would benefit her constituents.

I'm retiring from my job this year as principal, and somebody said, "Well, aren't you going to go do something with your doctorate?" and I said, "I've been doing stuff with my doctorate, ever since I started the program." The teachers have benefitted from it, the students [and] their parents. I've already been using all of that information, the whole time I was enrolled in the program.

She described with great enthusiasm her interview process for her dissertation, and the time she spent traveling to small towns and interviewing children and their families, and how much she "loved" meeting with them.

Another participant viewed the Ph.D. process as a tool to deepen her understanding of her topic and continue her passion of helping the young child to have an opportunity to eat well. Being placebound at the time, her discipline choices were limited, but her choice of Adult Organizational Leadership and Learning opened her eyes to adult learning and organizations. Both of these elements were woven into her dissertation research with the adult learning piece supporting her understanding of parents and the organizational piece expanding her knowledge of organizations that support mealtimes.

\section{*Content written by Lori Wahl and included with permission}




\section{Exhibit 4: Qualtrics}

The University of Idaho offers a Qualtrics account to all current student, faculty, and staff at the university. Log in is through the university's SSO (single sign-on) authentication with a valid NetID and password.

\section{Qualtrics}
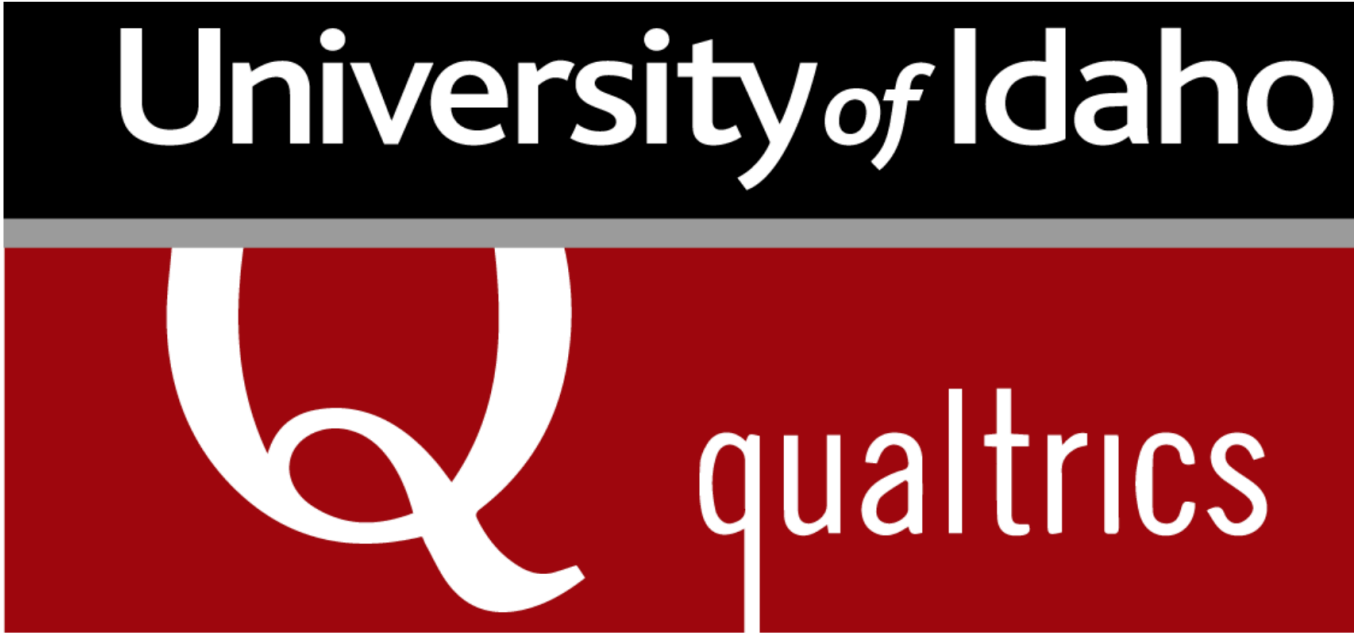

qualtrics

\section{What is Qualtrics?}

Qualtrics is an online data collection tool licensed by the university for use in academic-related research and administrative projects. Qualtrics allows users to create and administer surveys and web forms, and provides quantitative statistical analysis on the collected data.

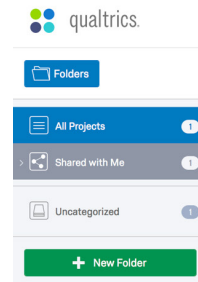

All Projects

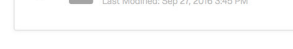




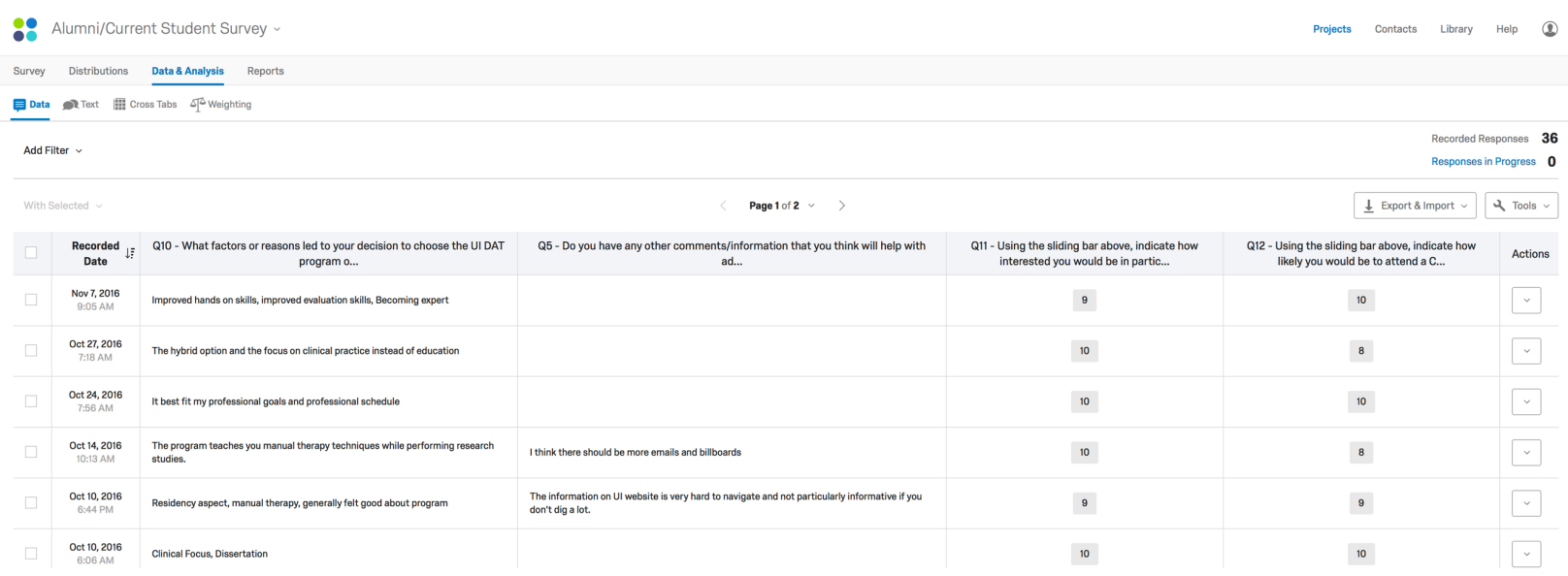

Data tab and the beginning of the data analysis process in Qualtrics.

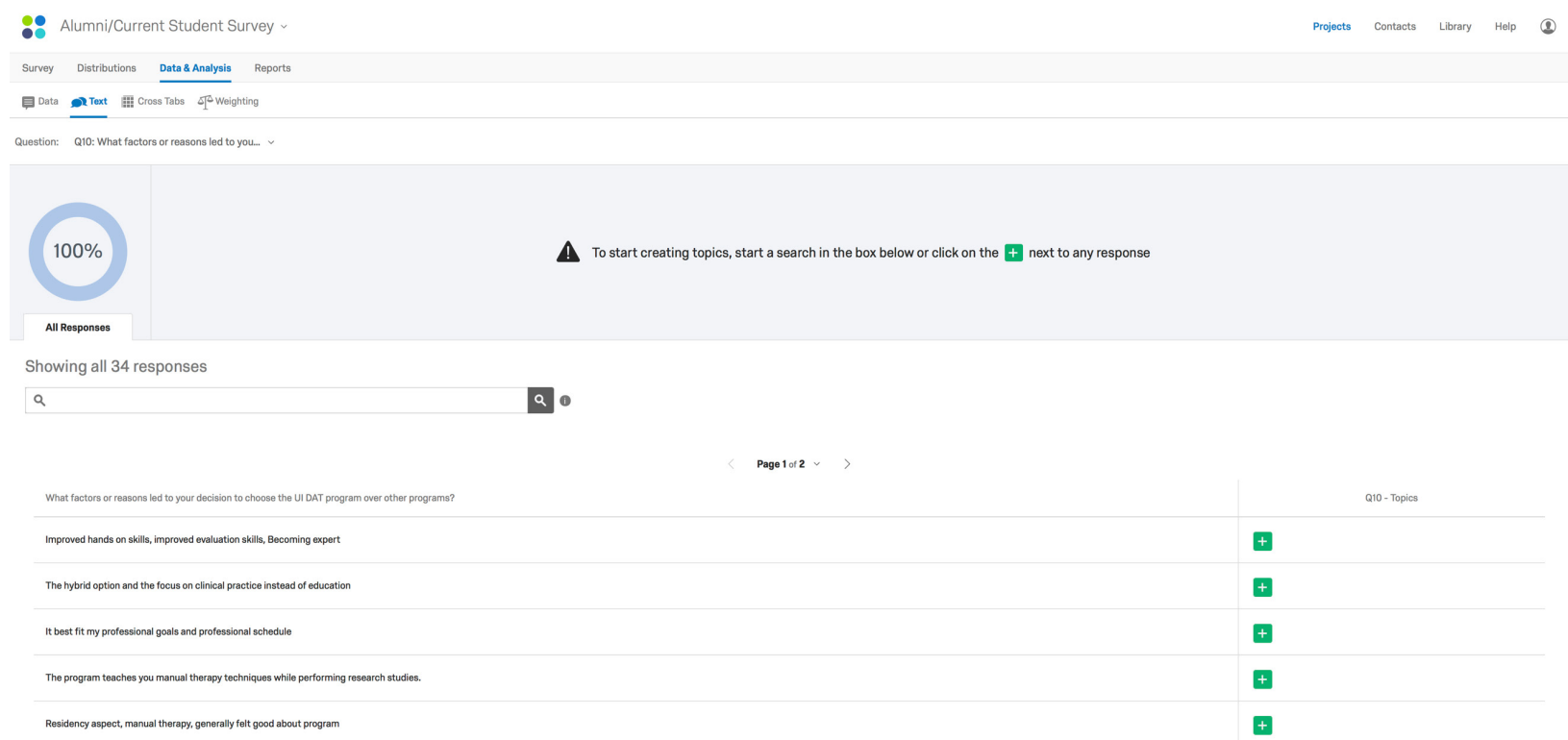

In Qualtrics, users are able to code themes, or topics, based on a word, group, or phrase. You can also exclude certain words (e.g., and, uh, um, it) from being recognized. 


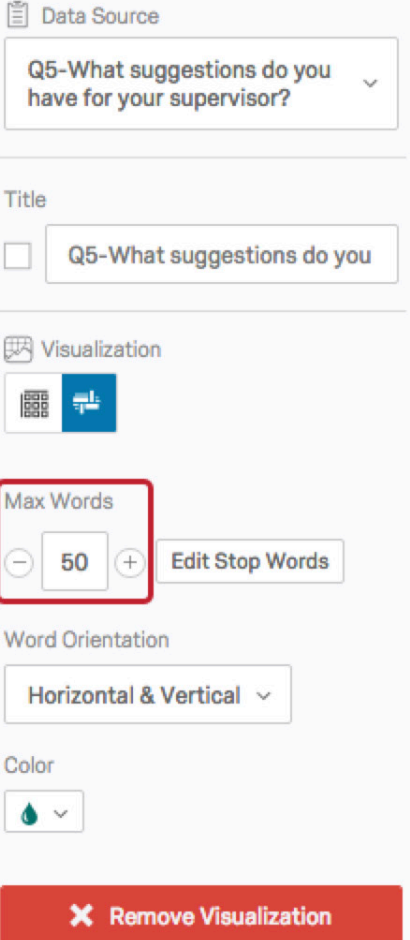

$<$ Previous Page

Next Page >

X Remove Visualization

Qualtrics also provides uses different visualization techniques, including word clouds, graphs, pie charts, etc. These can be found under "Reports". Word clouds through Qualtrics displays the words that are used most often through your data. The larger and darker the words are, the more frequent they appear. This helps identify themes/codes in your data. As part of word clouds, users can also add stop words. These will limit the amount of filler words (e.g., and) from being factored into the cloud. 


\section{Exhibit 5: Quality Matters Standards}

QUALITY MATTERS

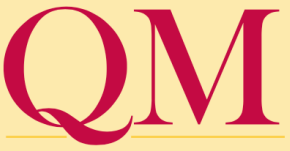

\section{Non-annotated Standards from the QM Higher} Education Rubric, Fifth Edition

For more information or access to the full annotated QM Rubric visit www.qualitymatters.org or email info@qualitymatters.org

Standards

Course

Overview

Introduction

1.1 Instructions make clear how to get started and where to find various course components.

1.2 Learners are introduced to the purpose and structure of the course.

1.3 Etiquette expectations (sometimes called "netiquette") for online discussions, email, and other forms of communication are clearly stated.

1.4 Course and/or institutional policies with which the learner is expected to comply are clearly stated, or a link to current policies is provided.

1.5 Minimum technology requirements are clearly stated and instructions for use provided

1.6 Prerequisite knowledge in the discipline and/or any required competencies are clearly stated.

1.7 Minimum technical skills expected of the learner are clearly stated.

1.8 The self-introduction by the instructor is appropriate and is available online.

1.9 Learners are asked to introduce themselves to the class.

Learning

Objectives

(Competencies)

2.1 The course learning objectives, or course/program competencies, describe outcomes that are measurable.

22 The module/unit learning objectives or competencies describe outcomes that are measurable and consistent with the course-level objectives or competencies.

2.3 All learning objectives or competencies are stated clearly and written from the learner's perspective.

2.4 The relationship between learning objectives or competencies and course activities is clearly stated.

2.5 The learning objectives or competencies are suited to the level of the course.

Assessment $\quad 3.1$ The assessments measure the stated learning objectives or competencies.

\begin{tabular}{l|l} 
and & 3.2 The course grading policy is stated clearly.
\end{tabular}

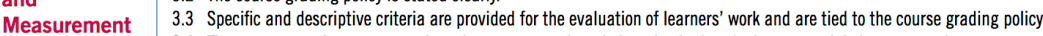

3.4 The assessment instruments selected are sequenced, varied, and suited to the learner work being assessed.

3.5 The course provides learners with multiple opportunities to track their learning progress.

Instructional 4.1 The instructional materials contribute to the achievement of the stated course and module/unit learning objectives or competencies.

\begin{tabular}{l|l} 
Materials & 4.2 Both the purpose of instructional materials and how the materials are to be used for learning activities are clearly explained.
\end{tabular}

4.3 All instructional materials used in the course are appropriately cited.

4.4 The instructional materials are current.

4.5 A variety of instructional materials is used in the course.

4.6 The distinction between required and optional materials is clearly explained.

Course

5.1 The learning activities promote the achievement of the stated learning objectives or competencies.

Activities and

Learner

Interaction

Course

Technology

5.3 The instructor's provide opportunities for interaction that support active learning.

tor's plan for classroom response time and feedback on assignments is clearly stated.

6.1 The tools used in the course support the learning objectives and competencies.

6.2 Course tools promote learner engagement and active learning

6.3 Technologies required in the course are readily obtainable.

6.4 The course technologies are current.

6.5 Links are provided to privacy policies for all external tools required in the course.

\begin{tabular}{l|l} 
Learner & 7.1 The course instructions articulate or link to a clear description of the technical support offered and how to obtain it.
\end{tabular}

\begin{tabular}{l|l} 
Support & 7.2 Course instructions articulate or link to the institution's accessibility policies and services.
\end{tabular}

7.3 Course instructions articulate or link to an explanation of how the institution's academic support services and resources can help Course instructions articulate or link to an explanation of how the

7.4 Course instructions articulate or link to an explanation of how the institution's student services and resources can help learners succeed and how learners can obtain them.

Accessibility $\quad 8.1$ Course navigation facilitates ease of use.

and Usability* 8.2 Information is provided about the accessibility of all technologies required in the course

8.3 The course provides alternative means of access to course materials in formats that meet the needs of diverse learners.

8.4 The course design facilitates readability.

8.5 Course multimedia facilitate ease of 


\section{Exhibit 6: Zoom Video Software}

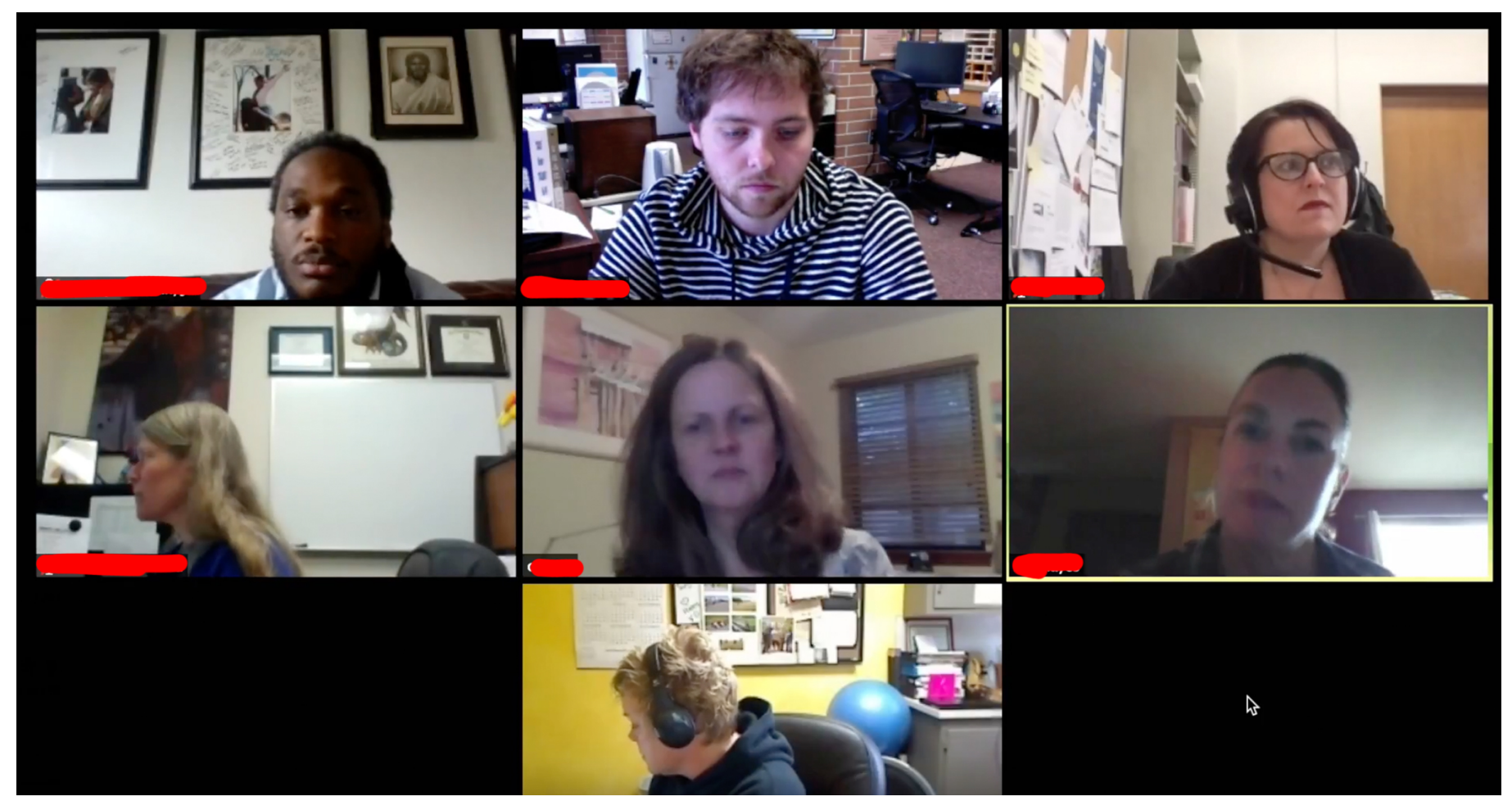

The class utilized the Zoom video software for the synchronous class sessions. This system allows instructors to record sessions, share screens, host meetings, etc. 


\section{Exhibit 7: Draft Syllabus for ED 589}
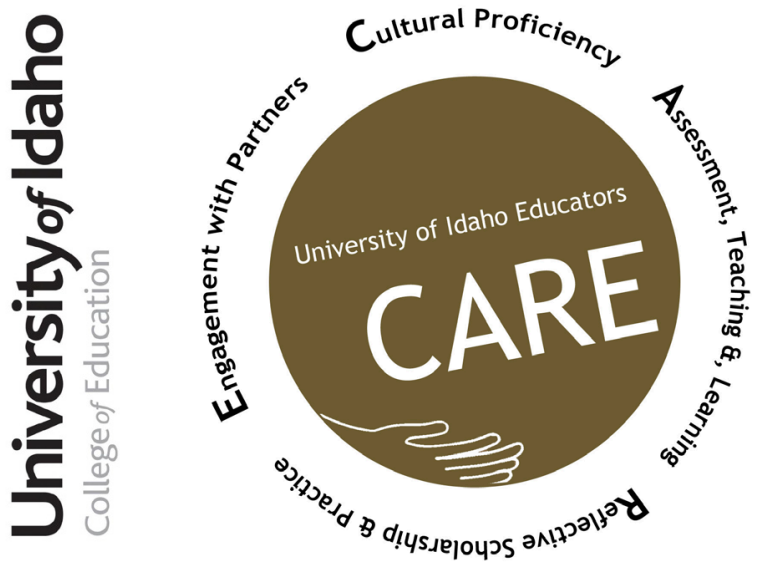

ED 589 Theoretical Applications and Design of Qualitative Research

Spring 2017

Number of Credits: 3

Class Meeting Place: Blackboard Learn

Instructor: Sydney Freeman, Jr., Ph.D., CFD

Email: sfreemanjr@uidaho.edu

Phone: 208-885-1011

\section{Course Description}

This course builds and expands on ED 574 Survey of Qualitative Research and examines qualitative research designs and the use of theory in qualitative research. The course will introduce ethnography, phenomenology, case study, narrative, historical, and action research designs and introduce the role of theory in guiding and informing research design and methods. The aim of the course is to give students the tools to conceptualize a research project and develop a peer-reviewed article. Unless otherwise noted and discussed with the instructor, ED 574 Survey of Qualitative Research is a required prerequisite for this course.

\section{Course Goals and Expectations}

To provide the student an opportunity to:

1. Design a qualitative research project.

2. Develop a literature review.

3. Analyze qualitative data.

4. Create a peer-reviewed manuscript.

5. Present qualitative research.

6. Describe how theory and various qualitative research designs can be used in research.

\section{Required Text:}

Anfara, V. A. \& Mertz, N. T. (2014) Theoretical Frameworks in Qualitative Research (2 ${ }^{\text {nd }}$ Ed.).

Belcher, W. L. (2009). Writing your journal article in twelve weeks: A guide to academic publishing success. Los Angeles, CA: SAGE.

Ravitch, S. M., Matthew, J., \& Riggan, M. (2016). Reason \& Rigor: How Conceptual Frameworks Guide Research (2 ${ }^{\text {nd }} E d$.).

Savin-Baden, M. \& Howell-Major, C. (2013). Qualitative Inquiry: The essential guide to theory and practice. New York: Routledge. 
Resource Link:

https://owl.english.purdue.edu/owl/resource/560/01/

Quality Matters Standards

\begin{tabular}{|l|l|}
\hline \multicolumn{1}{|c|}{ Standards } & \multicolumn{1}{c|}{ How Standards Are Met } \\
\hline - Course Overview and Introduction: The overall design of the course is \\
made clear to the learner at the beginning of the course.
\end{tabular}


- Assessment and Measurement: Assessments are integral to the learning process and are designed to evaluate learner progress in achieving the stated learning objectives or mastering the competencies.

\begin{tabular}{|c|c|}
\hline $\begin{array}{l}\text { - } 3.1 \text { The assess- } \\
\text { ments measure the } \\
\text { stated learning objec- } \\
\text { tives or competencies. }\end{array}$ & 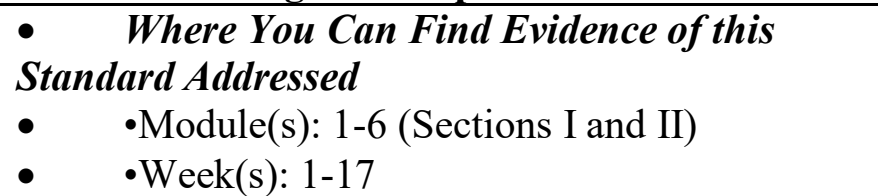 \\
\hline $\begin{array}{l}\text { - } 3.2 \text { The course grad- } \\
\text { ing policy is stated clearly. }\end{array}$ & $\begin{array}{l}\text { - Where You Can Find Evidence of this } \\
\text { Standard Addressed } \\
\bullet \quad \cdot \text { Module(s): Ground Rules for this } \\
\text { Course and Syllabus (BbLearn site) } \\
\bullet \quad \cdot \text { Week(s): N/A }\end{array}$ \\
\hline $\begin{array}{l}\text { - } 3.3 \text { Specific and } \\
\text { descriptive criteria are } \\
\text { provided for the evalua- } \\
\text { tion of learners' work and }\end{array}$ & $\begin{array}{l}\text { - Where You Can Find Evidence of this } \\
\text { Standard Addressed } \\
\bullet \quad \cdot \text { Module(s): Syllabus (BbLearn site, schedule } \\
\text { and syllabus) }\end{array}$ \\
\hline
\end{tabular}

- $\quad$ 4.1 The instructional materials contribute to the achievement of the stated course and module/unit learning objectives or competencies.
- $\quad$ 4.2 Both the purpose of instructional materials and how the materials are to be used for learning activities are clearly explained.
- Where You Can Find Evidence of this Standard Addressed

- $\quad$ Module(s): 1-6 (BbLearn site)

- $\quad$ Week(s): 1-17

- $\quad$ Activity(ies): 1-9

- $\quad$ The instructional material appear to be directly applicable to the learning activities. Explicitly stating how they do will remove any ambiguity.

- Where You Can Find Evidence of this Standard Addressed

- $\quad$ Module(s): 1-7 (BbLearn site, Learning Activities section II)

- Course Activities and Learner interaction: Course activities facilitate and support learner interaction and engagement.

- 5.1 The learning activities promote the achievement of the stated learning objectives or competencies.
Where You Can Find Evidence of this Standard Addressed

- $\quad$ Module(s): 1-6 (BbLearn site, Learning Activities section II)

- $\quad$ Week(s): 1-17 


\begin{tabular}{|c|c|}
\hline $\begin{array}{l}\text { - 5.2 Learning activities } \\
\text { provide opportunities for in- } \\
\text { teraction that support active } \\
\text { learning. }\end{array}$ & $\begin{array}{l}\text { - Where You Can Find Evidence of this Stand- } \\
\text { ard Addressed } \\
\text { - } \quad \text { Module(s): Discussion Board and Collabo- } \\
\text { rate Sessions (weekly meetings on Mondays at } 5 \\
\text { p.m. PST/6 p.m. MST) } \\
\text { - } \quad \text {-Week(s): } 1-17\end{array}$ \\
\hline $\begin{array}{l}\text { - } 5.3 \text { The instructor's } \\
\text { plan for } \\
\text { - classroom response } \\
\text { time and feedback on as- } \\
\text { signments is clearly stated. }\end{array}$ & $\begin{array}{l}\text { - Where You Can Find Evidence of this Stand- } \\
\text { ard Addressed } \\
\text { - } \quad \text { Module(s): Syllabus (BbLearn site, syllabus } \\
\text { and schedule) } \\
\text { - } \quad \text {-Week(s): N/A } \\
\text { - } \quad \text { Activity(ies): N/A }\end{array}$ \\
\hline \multicolumn{2}{|c|}{$\begin{array}{l}\text { - Course Technology: Course technologies support learners' achieve- } \\
\text { ment of course objectives or competencies. }\end{array}$} \\
\hline $\begin{array}{l}\text { - } 6.1 \text { The } 1 \\
\text { the course supr } \\
\text { ing objectives } c \\
\text { cies. }\end{array}$ & $\begin{array}{l}\text { - Where You Can Find Evidence of this Stand- } \\
\text { ard Addressed } \\
\text { • } \quad \text { Module(s): } 1-6 \text {, Collaborate Sessions } \\
\text { (web-based materials, recorded video tutori- } \\
\text { als, and live lectures) } \\
\text { - } \quad \text {-Week(s): } 1-17\end{array}$ \\
\hline $\begin{array}{l}-6.2 \text { Cours } \\
\text { mote learner en } \\
\text { active learning }\end{array}$ & $\begin{array}{l}\text { - Where You Can Find Evidence of this Stand- } \\
\text { ard Addressed } \\
\text { - } \quad \text { Module(s): } 6 \text { (online presenta- } \\
\text { tions), Collaborate Sessions, Discussion } \\
\text { Board, One-on-One Sessions } \\
-\quad \cdot \text { Week(s): } 1,3,4,6,8,11,12,13,14,15,17\end{array}$ \\
\hline
\end{tabular}

- Learner Support: The course facilitates learner access to institutional support services essential to learner success.

- $\quad$ 7.1 The course instructions articulate or - Where You Can Find Evidence of this Standlink to a clear description of the technical support offered and how to obtain it. ard Addressed

- $\quad$ Module(s): Welcome (BbLearn site, Section IV), Syllabus (BbLearn site, syllabus and schedule)

- $\quad$-Week(s): N/A

- $\quad$ Activity(ies): N/A

- $\quad$ 7.2 Course instructions articulate or link to the institution's accessibility policies and services.

- Where You Can Find Evidence of this Standard Addressed

- $\quad$-Module(s): Syllabus (BbLearn site, syllabus and schedule)

- $\quad$ Week(s): N/A 


\begin{tabular}{|c|c|}
\hline $\begin{array}{l}\text { - } \\
\text { Accessibility and usabi } \\
\text { accessibility and usability for }\end{array}$ & $\begin{array}{l}\text { lity: The course design reflects a commitment to } \\
\text { all learners. }\end{array}$ \\
\hline $\begin{array}{l}\text { 8.1 Course navigation } \\
\text { facilitates ease of use. }\end{array}$ & $\begin{array}{l}\text { - Where You Can Find Evidence of this Stand- } \\
\text { ard Addressed } \\
\text { - } \quad \text {-Module(s): All (BbLearn site) } \\
\text { - } \quad \text {-Week(s): } 1-17 \\
\text { - } \quad \text { Activity(ies): N/A }\end{array}$ \\
\hline $\begin{array}{l}\text { - } 8.2 \text { Information is pro- } \\
\text { vided about the accessibility } \\
\text { of all technologies required in } \\
\text { the course. }\end{array}$ & $\begin{array}{l}\text { - Where You Can Find Evidence of this Stand- } \\
\text { ard Addressed } \\
\text { - } \quad \text { Module(s): All (BbLearn site) } \\
\text { - } \quad \text {-Week(s): } 1-17 \\
\text { - } \quad \text { Activity(ies): N/A }\end{array}$ \\
\hline
\end{tabular}

\section{Learning Activities and Assignments}

\begin{tabular}{|l|c|}
\hline Assignment & Points Possible \\
\hline Class Introduction & 50 \\
\hline CITI certificate & 30 \\
\hline IRB Protocol Assignment & 100 \\
\hline Discussion & 60 \\
\hline Annotated Bibliography & 50 \\
\hline Abstract Proposal & 50 \\
\hline Methodology Presentation & 60 \\
\hline Article Proposal & 250 \\
\hline Interview Transcriptions/Description Table & 250 \\
\hline Final Paper & 250 \\
\hline Final Presentation & 50 \\
\hline Total & $1300 \mathrm{pts}$ \\
\hline
\end{tabular}


Weekly Schedule

\begin{tabular}{|c|c|c|}
\hline & Chapter & Assignments \\
\hline Week 1 & $\begin{array}{c}\text { Savin-Baden \& Howell-Major } \\
\text { Part } 1 \text { (Chapters 1-3) } \\
\text { Considering perspectives } \\
\end{array}$ & $\begin{array}{l}\text { Activity 1: Online Introduction } \\
\text { Due Sunday }\end{array}$ \\
\hline Week 2 & $\begin{array}{c}\text { Savin-Baden \& Howell-Major } \\
\text { Part } 2 \text { (Chapter 4-5) } \\
\text { Acknowledging a position } \\
\text { Belcher: Chapter } 3 \text { (Week 3) Advancing } \\
\text { Your Argument }\end{array}$ & $\begin{array}{c}\text { Activity 2: CITI Certificate } \\
\text { IRB Protocol Assignment } \\
\text { Due Sunday }\end{array}$ \\
\hline Week 3 & $\begin{array}{c}\text { Savin-Baden \& Howell-Major } \\
\text { Part } 3 \text { (Chapters 6-9) } \\
\text { Framing the study } \\
\text { Belcher: Chapter } 1 \text { (Week 1) Designing } \\
\text { Your Writing Plan } \\
\& \\
\text { Belcher: Chapter } 5 \text { (Week 5) Reviewing } \\
\text { the Related Literature }\end{array}$ & $\begin{array}{c}\text { Discussion Questions 1: BBLearn } \\
\text { Activity 3: Annotated Bibliography } \\
\text { Due Sunday }\end{array}$ \\
\hline Week 4 & $\begin{array}{c}\text { Savin-Baden \& Howell-Major } \\
\text { Part } 4 \text { (Chapters 10-19) } \\
\text { Choosing a research approach } \\
\text { Belcher: Chapter 6 (Week 6) Strengthen- } \\
\text { ing Your Structure } \\
\text { Anfara \& Metz } \\
\text { Chapter One Setting the Stage } \\
\text { Ravitch, Matthew, \& Riggan } \\
\text { Chapter One Introduction to Conceptual } \\
\text { Frameworks }\end{array}$ & $\begin{array}{c}\text { Activity 4: Abstract } \\
\text { Discussion Question 2: BBLearn } \\
\text { Due Sunday }\end{array}$ \\
\hline Week 5 & $\begin{array}{c}\text { Savin-Baden \& Howell-Major } \\
\text { Part } 5 \text { (Chapters 20-26) } \\
\text { Collecting data } \\
\text { Anfara \& Metz } \\
\text { Chapter Six Using Multiple Theoretical } \\
\text { Frameworks to Study Organizational } \\
\text { Changes and Identity } \\
\text { Ravitch, Matthew \& Riggan } \\
\text { Chapter Two Why Conceptual Frame- } \\
\text { works? }\end{array}$ & $\begin{array}{c}\text { Activity 5: Methodology Presentation } \\
\text { Due Sunday }\end{array}$ \\
\hline
\end{tabular}




\begin{tabular}{|c|c|c|}
\hline & Chapter & Assignments \\
\hline Week 6 & $\begin{array}{c}\text { Belcher: Chapter 2 (Week 2) } \\
\text { Starting your article } \\
\text { Anfara \& Metz } \\
\text { Chapter Four Black Feminist Thought and } \\
\text { Examining the Experiences of Black } \\
\text { Graduate Women in the Academy } \\
\text { Chapter Seven Using "Othermothering" to } \\
\text { Study Administrative Work Life at Histori- } \\
\text { cally Black Colleges and Universities } \\
\text { Ravitch, Matthew, Riggan } \\
\text { Chapter Four Excavating Questions: Con- } \\
\text { ceptual Frameworks, Research Questions, } \\
\text { and Research Design } \\
\text { Chapter Five The Role of the Conceptual } \\
\text { Framework in Data Collection and Field- } \\
\text { work }\end{array}$ & $\begin{array}{c}\text { One-on-One Sessions: BBLearn } \\
\text { Discussion Questions 3: BBLearn } \\
\text { Due Sunday }\end{array}$ \\
\hline Week 7 & $\begin{array}{c}\text { Anfara \& Metz } \\
\text { Chapter Twelve Theoretical Frameworks } \\
\text { in Brief } \\
\text { Chapter Thirteen Closing the Loop } \\
\text { Ravtich, Matthew, \& Riggan } \\
\text { Chapter Six Conceptual Frameworks and } \\
\text { the Analysis of Data } \\
\text { Chapter Seven Expanding the Conversa- } \\
\text { tion, Extending the Argument: The Role of } \\
\text { Conceptual Frameworks in Present- } \\
\text { ing, Explaning, and Contextualizing Find- } \\
\text { ings } \\
\text { Chapter Nine The Conceptual Framework } \\
\text { as Guide and Ballast }\end{array}$ & $\begin{array}{c}\text { Activity 6: Research Proposal } \\
\text { Due Sunday }\end{array}$ \\
\hline Week 8 & $\begin{array}{c}\text { Savin-Baden \& Howell-Major } \\
\text { Part 6: (Chapter 27-30) } \\
\text { Working with data and findings }\end{array}$ & $\begin{array}{c}\text { Discussion Questions 4: BBLearn } \\
\text { Due Sunday }\end{array}$ \\
\hline Week 9 & $\begin{array}{c}\text { Belcher: Chapter } 7 \text { (Week 7) Presenting } \\
\text { Your Evidence }\end{array}$ & $\begin{array}{c}\text { Activity 7: } \\
\text { Interview Transcriptions } \\
\text { Due Sunday } \\
\end{array}$ \\
\hline Week 10 & \multicolumn{2}{|c|}{ Spring Recess-No Class } \\
\hline
\end{tabular}




\begin{tabular}{|c|c|c|}
\hline & Chapter & Assignments \\
\hline Week 11 & $\begin{array}{l}\text { Belcher: Chapter } 9 \text { (Week 9) Giving, } \\
\text { Getting, and Using Other's Feedback }\end{array}$ & $\begin{array}{l}\text { One-on-One Sessions: BBLearn } \\
\text { Due Sunday }\end{array}$ \\
\hline Week 12 & $\begin{array}{l}\text { Belcher: Chapter 8 (Week 8) Opening } \\
\text { and Concluding Your Article }\end{array}$ & $\begin{array}{c}\text { One-on-One Sessions: BBLearn } \\
\text { Due Sunday }\end{array}$ \\
\hline Week 13 & $\begin{array}{c}\text { Savin-Baden \& Howell-Major } \\
\text { Part 7: Writing about the research } \\
\text { (Chapters 31-32) } \\
\text { Belcher: Chapter 10 (Week 10) Editing } \\
\text { Your Sentences }\end{array}$ & $\begin{array}{c}\text { Discussion Questions 5: BBLearn } \\
\text { Due Sunday }\end{array}$ \\
\hline Week 14 & $\begin{array}{l}\text { Belcher: Chapter } 11 \text { (Week 11) Wrap- } \\
\text { ping Up Your Article }\end{array}$ & $\begin{array}{l}\text { One-on-One Sessions: BBLearn } \\
\text { Due Sunday }\end{array}$ \\
\hline Week 15 & $\begin{array}{c}\text { Belcher: Chapter } 4 \text { (Week 4) Selecting a } \\
\text { Journal }\end{array}$ & $\begin{array}{c}\text { Discussion Question 6: BBLearn } \\
\text { Due Sunday }\end{array}$ \\
\hline Week 16 & $\begin{array}{c}\text { Belcher: Chapter } 12 \text { (Week 12) Sending } \\
\text { Your Article! } \\
\text { Belcher: Chapter } 13 \text { (Week X) Respond- } \\
\text { ing to Journal Decisions }\end{array}$ & $\begin{array}{l}\text { Activity 8: Final Paper } \\
\text { Due Sunday }\end{array}$ \\
\hline Week 17 & No Reading & $\begin{array}{c}\text { Assignment 9: Presentation Week } \\
\text { Due Sunday }\end{array}$ \\
\hline
\end{tabular}

\section{Course Assignments}

The week will begin every Monday, with all readings, assignments, and activities due that upcoming Sunday (i.e., Week 3 begins Monday, January $23^{\text {rd }}$, and the assignments for that week will be due on Sunday, January $29^{\text {th }}$.).

\section{Discussions- (6 in total for 10pts each)}

One or more questions/prompts will be listed for whole class discussion on various weeks. These may be related to the textbook chapters, weekly readings/resources, research to share, and general course topics. Discussions will be evaluated on three elements: quality, timeliness and quantity. All three are roughly weighted equally.

\section{Quality}

Messages that add value to the discussion. In short, this means not simple "I agree" posts. So, how do you add value? Here are some ways:

1. Post an original answer to a question posed by a classmate

2. Indicate whether you agree or disagree with what another person posted, and why.

3. Consider using the $2 \times 2$ technique - give 2 instances why you agree with the posts and 2 instances why you disagree with the post.

4. Ask another person a question. 
5. Experiences and stories that relate to the topic are great. These can be from work, volunteering, education, your personal life, or elsewhere.

6. Relate a recent news event, article you have read, or such. Don't simply link to it; explain the relevance. Come up with a scenario/example of how you might apply the materials (perhaps ideas for your research proposal).

7. At the end of the week, summarize the discussion for a particular question or an aspect of the critique.

\section{$\underline{\text { Timeliness }}$}

Research and experience shows that students get the most out of an online course by participating in the discussions early and following them as they evolve. Each of you has significant contributions you can make to the class, so answer the questions early.

\section{Quantity}

The hardest of the three to address is quantity. I am not establishing a minimum nor maximum number of posts as a requirement. I do not expect you to answer each of them, but to answer at least one or two of them and get involved in discussions with the rest.

\begin{tabular}{|l|}
\hline Discussion 1: BBLearn \\
\hline Discussion 2: BBLearn \\
\hline Discussion 3: BBLearn \\
\hline Discussion 4: BBLearn \\
\hline Discussion 5: BBLearn \\
\hline Discussion 6: BBLearn \\
\hline
\end{tabular}

\section{Activities}

\section{Activity 1: Class Introduction (50 pts)}

For this assignment you will introduce yourself to the class. Include the following:

1. A picture of you. These pictures need to be small files to upload properly.

2. Biographical information about yourself.

3. A statement about what research topic you will be focusing on in this course. Additionally, what research means to you and discuss what experience you've had with research.

4. You will need to write a 3-paragraph response to the speech and respond to your classmates via the discussion board. The questions that you will need to answer are: What is an intellectual? Why is it important to be an intellectual? Who can be an intellectual? 


\section{Activity 2: CITI Protecting Human Research Participants Certificate (30 pts.)}

For this assignment, you will be expected to complete an on-line course that will take about an hour which discusses various aspects of Human Subjects research. After completing the assignment, you will need to attach your certificate of completion showing you have taken the CITI exam.

\section{IRB Protocol Assignment (100 pts)}

For this assignment, you will be expected to complete the University of Idaho IRB Protocol Submission process. The information you provide will be associated with the topic you will be researching throughout the semester. After completing the IRB form provided in the online portal you will need to create a pdf version of the completed submission and upload to the Assignment Portal on BbLearn.

\section{IRB Protocol Assignment Rubric}

\section{Task}

Possible Points

Start (Create appropriate Title)

Checklist

- Identify the appropriate checklist

- Determine how you will interact with your subjects

- Decide protocol type

- Decide submission type

- Identify appropriate design methodology

- Relevant Expertise

- Describe the purpose of your research

- Describe the research design

- Describe the subject/participant population

- Describe the procedures in detail from start to finish

Exemption

- Decide if the project meets criteria for exempt status

- Indicate the appropriate exemption status

- Provide a brief explanation of why you chose the exemption category you selected

- Describe how you will maintain anonymity and confidentiality 
- Indicate the data collection methods that you will use

- Indicate if compensation will be provided to the participants

- Number of participants

- Age ranges

- Recruiting methods

- Flyer locations

- Other recruiting methods

- Exclusion details

- Consent checklist

- Parental consent

- Waiver of consent

- Etc.

Data

- International: HIPAA applicability

- HIPAA applicability

- FERPA applicability

\section{Activity 3: Annotated Bibliography (50 pts)}

Each student will be expected to develop an annotated bibliography on the topic of the development of a qualitative dissertation. Students must provide at least fifteen (15) references to receive full points for this assignment. These references can be used in the development of the final paper for this course. However, additional references will be expected to be included in the final draft of your paper at the course.

\section{Activity 4: Abstract (50 pts)}

Each student will be expected to develop an abstract based on their given research topic. Following the abstract activity in Belcher's text on pages 54-64. Each abstract will be assessed using the rubric below.

\section{Research Proposal (Abstract) Rubric}

\begin{tabular}{|l|c|}
\hline Question to be addressed & Points Possible \\
\hline Why did you embark on the project? & 10 \\
\hline What is your study about? & 10 \\
\hline What research methodology and approach will you use? & 10 \\
\hline What is your research question? & 10 \\
\hline What do you hope to find? & $\mathbf{5 0}$ \\
\hline TOTAL & \\
\hline
\end{tabular}




\section{Activity 5: Methodology Presentation (60 pts)}

Students will be assigned a research methodology (i.e., case study, grounded theory, phenomenology, ethnography) as research approaches. They will have to do a presentation describing the research approach that they have been assigned. They will need to describe 1) origin of the methodology, 2) the various types of research designs within the research approach, 3) advantages and challenges related to each approach, 4) and how to conduct an analysis and sample size given the approach. Presentation will be done via BBLearn Collaborate.

\section{Activity 6: Research Proposal (250 pts)}

Students will write a 10-12 page paper; double spaced, size 12 times new roman font; excluding title page and reference page. Include the following:

\section{- A descriptive title}

- Introduction: Engage your reader in the topic, introducing the topic and research

- Purpose and questions to be addressed. Entice us to read your paper.

Provide a roadmap for where we are going in the paper.

- Literature review: Situate your work in the context of current scholarly literature. This should be a comprehensive review of the literature, written concisely. Substantiate how your study will contribute to the field of inquiry.

- Research design \& methods statement: This is a clear, concise methods statement (the design of your study, the theoretical and methodological framework from which you are working, data collection procedures, setting and/or participant descriptions). Be sure to cite the scholars who have informed your methods.

$\begin{array}{ll}\text { Task } & \text { Points } \\ \text { Descriptive Title } & 50 \\ \text { Introduction } & 50 \\ \text { Purpose and Questions } & 50 \\ \text { Literature Review } & 50 \\ \text { Research Design \& Methods Statement } & 50 \\ \text { Total } & \mathbf{2 5 0}\end{array}$

\section{Activity 7: Interview Transcriptions and Demographic Summary Table (250 pts)}

You will be expected to conduct 5 interviews and transcribe each based on the topic that you have engaged in throughout the semester. You will also be expected to develop a demographic summary table and a coding summary document. This is also one of the most important activities in the class and will be graded as such. Each should be uploaded to BBLearn for the instructor's review.

Interview Transcriptions and Analysis Rubric

\begin{tabular}{lc}
\multicolumn{1}{c}{ Task } & Points Possible \\
Completion of interviews & 100 \\
Demographic Summary Table & 50 \\
Coding Summary Document & 100 \\
Total & 250
\end{tabular}




\section{Activity 8: Findings and Conclusion (Final paper)(250 pts)}

You will be expected to synthesize your findings that you collected throughout the semester and describe them in one paper. The paper should be between 20 to 25 pages excluding the references and title page. You will primarily be graded on the organization and quality of grammar and spelling throughout the paper. This is also one of the most important activities in the class and will be graded as such.

\section{Findings Chapter Elements}

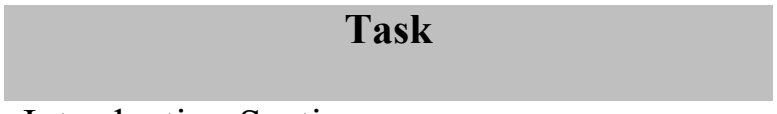

Introduction Section

- Research Question

- Purpose Statement

Review of Literature Section

- Important Literature

- Theoretical/Conceptual Framework

Methodology Section

- Research Design

- Participants

- Limitations

Findings Section

- Provide quotations

- Compare findings to Theoreti-

cal/Conceptual Framework

Conclusion Section

- Discussion

- Implications for Policy and practice 


\section{AOLL Writing Elements Rubric}

\begin{tabular}{|c|c|c|c|c|}
\hline Criteria & Exemplary & Good & Acceptable & Unacceptable \\
\hline Purpose & $\begin{array}{l}\text { The writer's cen- } \\
\text { tral purpose or ar- } \\
\text { gument is readily } \\
\text { apparent to the } \\
\text { reader. }\end{array}$ & $\begin{array}{l}\text { The writing has a } \\
\text { clear purpose or } \\
\text { argument, but may } \\
\text { sometimes digress } \\
\text { from it. }\end{array}$ & $\begin{array}{l}\text { The central purpose } \\
\text { or argument is not } \\
\text { consistently clear } \\
\text { throughout the pa- } \\
\text { per. }\end{array}$ & $\begin{array}{l}\text { The purpose or ar- } \\
\text { gument is generally } \\
\text { unclear. }\end{array}$ \\
\hline Content & $\begin{array}{l}\text { Balanced presenta- } \\
\text { tion of relevant and } \\
\text { legitimate infor- } \\
\text { mation that clearly } \\
\text { supports a central } \\
\text { purpose or argu- } \\
\text { ment and shows a } \\
\text { thoughtful, in- } \\
\text { depth analysis of a } \\
\text { significant topic. } \\
\text { Reader gains im- } \\
\text { portant insights. }\end{array}$ & $\begin{array}{l}\text { Information pro- } \\
\text { vides reasonable } \\
\text { support for a cen- } \\
\text { tral purpose or ar- } \\
\text { gument and dis- } \\
\text { plays evidence of a } \\
\text { basic analysis of a } \\
\text { significant topic. } \\
\text { Reader gains some } \\
\text { insights. }\end{array}$ & $\begin{array}{l}\text { Information supports } \\
\text { a central purpose or } \\
\text { argument at times. } \\
\text { Analysis is basic or } \\
\text { general. Reader } \\
\text { gains few insights. }\end{array}$ & $\begin{array}{l}\text { Central purpose or } \\
\text { argument is not } \\
\text { clearly identified. } \\
\text { Analysis is vague or } \\
\text { not evident. Reader } \\
\text { is confused or may } \\
\text { be misinformed. }\end{array}$ \\
\hline Organization & $\begin{array}{l}\text { The ideas are ar- } \\
\text { ranged logically to } \\
\text { support the pur- } \\
\text { pose or argument. } \\
\text { They flow smooth- } \\
\text { ly from one to an- } \\
\text { other and are clear- } \\
\text { ly linked to each } \\
\text { other. The reader } \\
\text { can follow the line } \\
\text { of reasoning. }\end{array}$ & $\begin{array}{l}\text { The ideas are ar- } \\
\text { ranged logically to } \\
\text { support the central } \\
\text { purpose or argu- } \\
\text { ment. They are } \\
\text { usually clearly } \\
\text { linked to each oth- } \\
\text { er. For the most } \\
\text { part, the reader can } \\
\text { follow the line of } \\
\text { reasoning. }\end{array}$ & $\begin{array}{l}\text { In general, the writ- } \\
\text { ing is arranged logi- } \\
\text { cally, although occa- } \\
\text { sionally ideas fail to } \\
\text { make sense together. } \\
\text { The reader is fairly } \\
\text { clear about what } \\
\text { writer intends. }\end{array}$ & $\begin{array}{l}\text { The writing is not } \\
\text { logically organized. } \\
\text { Frequently, ideas } \\
\text { fail to make sense } \\
\text { together. The reader } \\
\text { cannot identify a } \\
\text { line of reasoning and } \\
\text { loses interest. }\end{array}$ \\
\hline Tone & $\begin{array}{l}\text { The tone is con- } \\
\text { sistently profes- } \\
\text { sional and appro- } \\
\text { priate for an aca- } \\
\text { demic research } \\
\text { paper. }\end{array}$ & $\begin{array}{l}\text { The tone is general- } \\
\text { ly professional. } \\
\text { For the most part, it } \\
\text { is appropriate for } \\
\text { an academic re- } \\
\text { search paper. }\end{array}$ & $\begin{array}{l}\text { The tone is not con- } \\
\text { sistently profession- } \\
\text { al or appropriate for } \\
\text { an academic re- } \\
\text { search paper. }\end{array}$ & $\begin{array}{l}\text { The tone is unpro- } \\
\text { fessional. It is not } \\
\text { appropriate for an } \\
\text { academic research } \\
\text { paper. }\end{array}$ \\
\hline
\end{tabular}




\begin{tabular}{|c|c|c|c|c|}
\hline Criteria & Exemplary & Good & Acceptable & Unacceptable \\
\hline $\begin{array}{l}\text { Sentence } \\
\text { Structure }\end{array}$ & $\begin{array}{l}\text { Sentences are well- } \\
\text { phrased and varied } \\
\text { in length and struc- } \\
\text { ture. They flow } \\
\text { smoothly from one } \\
\text { to another. }\end{array}$ & $\begin{array}{l}\text { Sentences are well- } \\
\text { phrased and there is } \\
\text { some variety in } \\
\text { length and struc- } \\
\text { ture. The flow } \\
\text { from sentence to } \\
\text { sentence is general- } \\
\text { ly smooth. }\end{array}$ & $\begin{array}{l}\text { Some sentences are } \\
\text { awkwardly con- } \\
\text { structed so that the } \\
\text { reader is occasional- } \\
\text { ly distracted. }\end{array}$ & $\begin{array}{l}\text { Errors in sentence } \\
\text { structure are fre- } \\
\text { quent enough to be a } \\
\text { major distraction to } \\
\text { the reader. }\end{array}$ \\
\hline Word Choice & $\begin{array}{l}\text { Word choice is } \\
\text { consistently precise } \\
\text { and accurate. }\end{array}$ & $\begin{array}{l}\text { Word choice is } \\
\text { generally good. } \\
\text { The writer often } \\
\text { goes beyond the } \\
\text { generic word to } \\
\text { find one more pre- } \\
\text { cise and effective. }\end{array}$ & $\begin{array}{l}\text { Word choice is } \\
\text { merely adequate, } \\
\text { and the range of } \\
\text { words is limited. } \\
\text { Some words are } \\
\text { used inappropriate- } \\
\text { ly. }\end{array}$ & $\begin{array}{l}\text { Many words are } \\
\text { used inappropriate- } \\
\text { ly, confusing the } \\
\text { reader. }\end{array}$ \\
\hline Length & $\begin{array}{l}\text { Paper is the num- } \\
\text { ber of pages speci- } \\
\text { fied in the assign- } \\
\text { ment. }\end{array}$ & & & $\begin{array}{l}\text { Paper has more or } \\
\text { fewer pages than } \\
\text { specified in the as- } \\
\text { signment. }\end{array}$ \\
\hline
\end{tabular}

\section{Activity 9: Power Point Presentation (100 pts)}

This is a group assignment. You will work along with your colleagues to develop a presentation that summarizes your findings and provides recommendations for future policy and practice. Each person will present for five minutes. These presentations will be conducted live via bblearn collaborate:

\section{Power Point Presentation Rubric}

\begin{tabular}{lc}
\multicolumn{1}{c}{ Task } & Points Possible \\
Explanation of Ideas \& Information & 25 \\
Organization & 25 \\
Voice & 25 \\
Implications for Policy \& Practice & 25 \\
Total & 100
\end{tabular}

\section{One-on-One sessions}

This class is structured differently than most on-line classes as it is structured primarily for opportunities for individual mentoring by the faculty member. So throughout the course students can set up individual bblearn collaborate sessions to be assisted by the instructor. 


\section{University of Idaho Classroom Learning Civility Clause}

In any environment in which people gather to learn, it is essential that all members feel as free and safe as possible in their participation. To this end, it is expected that everyone in this course will be treated with mutual respect and civility, with an understanding that all of us (students, instructors, professors, guests, and teaching assistants) will be respectful and civil to one another in discussion, in action, in teaching, and in learning.

Should you feel our classroom interactions do not reflect an environment of civility and respect, you are encouraged to meet with your instructor during office hours to discuss your concern. Additional resources for expression of concern or requesting support include the Dean of Students office and staff (56757), the UI Counseling \& Testing Center's confidential services (5-6716), or the UI Office of Human Rights, Access, \& Inclusion (5-4285).

\section{University of Idaho (UI) Nondiscrimination Policy}

It is UI policy to prohibit and eliminate discrimination on the basis of race, color, national origin, religion, sex, sexual orientation and gender identity/expression, age, disability, or status as a Vietnam-era veteran. This policy applies to all programs, services, and facilities, and includes, but is not limited to, applications, admissions, access to programs and services, and employment. Such discrimination is prohibited by titles VI and VII of the Civil Rights Act of 1964, title IX of the Educational Amendments of 1972, sections 503 and 504 of the Rehabilitation Act of 1973, the Vietnam Era Veterans' Readjustment Assistance Act of 1974, the Age Discrimination Act of 1975, the Age Discrimination in Employment Act Amendments of 1978, the Americans with Disabilities Act of 1990, the Civil Rights Act of 1991, other federal and state statutes and regulations, and university commitments (see Faculty Staff Handbook (FSH) 3060). Sexual harassment violates state and federal law and policies of the Board of Regents, and is expressly prohibited, as stated in FSH 3220. The University of Idaho also prohibits discrimination on the basis of sexual orientation, as stated in FSH 3215. The entire FSH can be accessed online at http://www.webs.uidaho.edu/fsh. Questions or concerns about the content and application of these laws, regulations or University policy may be directed to: the Office of Human Rights, Access \& Inclusion (208-885-4285); Regional Office for Civil Rights, U.S. Department of Education in Seattle (206-2207900); Equal Employment Opportunity Commission, Seattle District Office (206-220-6883); or Pacific Regional Office of Federal Contract Compliance Programs, U.S. Department of Labor in San Francisco (415-848-6969). Complaints about discrimination or harassment should be brought to the attention of the Office of Human Rights, Access \& Inclusion (885-4285). Retaliation for bringing forward a complaint is prohibited by FSH 3810 .

\section{Library Resources (On Campus Classes)}

As a UI student, you not only have access to valuable print and electronic resources from the university's library, but you also have the ability to set up a personalized reference appointment with one of the librarians. If you have assignments or research questions and aren't sure how to make the most of library resources, feel free to contact the College of Education liaison librarian with questions: Rami Attebury, 885-2503, rattebur@uidaho.edu. As always, you may also stop by the reference desk anytime Monday to Thursday 9 to 9, Friday 9 to 5, and Sunday 1-9, 208-885-6584, or visit http://www.lib.uidaho.edu for email or IM assistance. 


\section{Library Resources (Distance Education/Centers Classes)}

As a UI student from outside of Moscow, you have access to valuable electronic and print resources from the university's library. To learn more about using library resources from a distance, visit the library's Off-Campus Access webpage at http://www.lib.uidaho.edu/offcampus/index.html. Live reference/research assistance is available Monday to Thursday 9 a.m. to 9 p.m., Friday 9 a.m. to 5 p.m., and Sunday 1 to 9 p.m. Just call 208-885-6584, email libref@uidaho.edu, text 208-856-0814, or IM from http://www.lib.uidaho.edu. In addition, please feel free to contact the College of Education liaison librarian, Rami Attebury, directly at 208-885-2503 or rattebur@uidaho.edu.

\section{Grievance Policy}

Information concerning student grade appeal procedures and non-academic grievances and appeals may be found in the University of Idaho Catalog.

\section{SYLLABUS CHANGE POLICY}

This syllabus is a guide for the course and is subject to change with advanced notice.

Reasonable accommodations are available for students who have documented temporary or permanent disabilities. All accommodations must be approved through Disability Support Services located in the Idaho Commons Building, Room 306 in order to notify your instructor(s) as soon as possible regarding accommodation(s) needed for the course.

\section{Grading Policy}

The most important criteria for grading are thoughtfulness, completeness, and quality. The effort you put into your assignments (process) contributes to your success on the final outcome (product).

Assignments that have not been demonstrably spell-checked, grammar-checked, and proofread will not be accepted. Unacceptable assignments will receive a zero and may be resubmitted (with a penalty) at my discretion. Please note that all of your work for this course must be original (see Academic Dishonesty Policy section below for more information).

Letter grades will be allocated on the following scale:

90 to 100 percent $=\mathrm{A}$

89 to 80 percent $=\mathrm{B}$

79 to 70 percent $=\mathrm{C}$

69 to 60 percent $=\mathrm{D}$

59 percent and below $=\mathrm{F}$

\section{Course Policies}

An important note about online learning: Please remember that the major difference with an online course is that communication is solely by written word. Therefore body language, voice tone, and instantaneous listener feedback found in the traditional classroom are all absent. This needs to be taken into account when contributing messages to a discussion and when reading them. 
Keep these points in mind:

- Written communication can easily be misinterpreted so avoid the use of strong or offensive language.

- In general, avoid humor and sarcasm as the absence of facial or voice cues can make it difficult for the reader to comprehend.

- If a classmate states something you find offensive, discuss it with the professor. What you may find offensive may have been unintentional and may be cleared up by the professor.

- Always think carefully about the content of your text before submitting it.

Once the message is sent to the group, there is no taking it back. Poor grammar and spelling can result in lost points.

- A fully online classroom is still a classroom, and comments that would be inappropriate in a regular classroom are likely to be inappropriate in your online class as well. Always treat your instructor and your classmates with respect.

- Before adding your comments, read the thread of your fellow classmates' comments. You want to relate your comments based on the discussion in progress. It can also be rude to ignore your classmates' contributions.

\section{Late Work:}

Any work submitted after the due date without prior permission will be docked 10 percent off the top and then graded as normal (i.e., the assignment will automatically receive a B grade or lower) providing the assignment is turned in within 24 hours of the time it is due. As assignment not turned in within 24 hours of the time due will result in a lowering of 20 percent of your grade. After 48 hours, the paper will receive 30 percent off. On the fourth day, the assignment will no longer be accepted for submission.

**All papers will be submitted through blackboard, unless otherwise noted. I will grade ONLY the draft that is uploaded into the system. Double check that you are submitting your final version. Upload all assignments as a .docx or .pdf attachment.

Incomplete Grades: Do not expect an incomplete for the course without extreme and unforeseen mitigating circumstances. A grade of "Incomplete" is assigned only when the student has been in attendance and has done passing work up to a time within three weeks of the close of the semester, or within one week of the close of the summer session. It may be assigned only upon agreement of the student and course instructor when extenuating circumstances make it impossible for the student to complete course requirements on time (Extenuating circumstances include serious illness, car accidents, death of a family member, etc. It does not include lateness due to procrastination, the student's desire to do extra work to raise his/her grade, allowing a student to retake the course, etc.).

Communication: You are required to check whatever email account you have connected to Blackboard $\mathrm{Bb}$ on a regular basis. I will post announcements using the Announcements feature on $\mathrm{Bb}$ but I will also send out email using $\mathrm{Bb}$ to provide announcements, grading updates, changes to course readings, etc. Please include your name in the body of the email and the course name in the subject line. I will make every effort to respond to email within 24 hours (Mon-Fri); if I do not respond within 36 hours, email me again, as your message might have been lost or misdirected.

\section{Academic Integrity}


The University of Idaho has as one of its core values the ideal of academic honesty and integrity. University of Idaho students live and work in a collegiate community, which emphasizes their responsibility for helping to determine and enforce appropriately high standards of academic conduct. The faculty of the University of Idaho expects all students to adhere to the highest standards of academic honesty, and to refrain from any action, which infringes upon academic freedom of other members of the academic community. Please refer to the University of Idaho - Student Code of Conduct Article II-Academic Honesty.

\section{Academic Dishonesty Policy}

Academic dishonesty occurs when a student uses or attempts to use unauthorized information in the taking of an exam; or submits as his or her own work themes, reports, drawings, laboratory notes, or other products prepared by another person; or knowingly assists another student in such acts or plagiarism. Such behavior is abhorrent to the university, and students found responsible for academic dishonesty face expulsion, suspension, conduct probation, or reprimand. Instances of academic dishonesty ultimately affect all students and the entire university community by degrading the value of diplomas when some are obtained dishonestly, and by lowering the grades of students working honestly.

Examples of specific acts of academic dishonesty include but are not limited to:

1.Obtaining unauthorized information. Information is obtained dishonestly, for example, by copying graded homework assignments from another student, by working with another student on a take---------home test or homework when not specifically permitted to do so by the instructor, or by looking at your notes or other written work during an examination when not specifically permitted to do so.

2.Tendering of information. Students may not give or sell their work to another person who plans to submit it as his or her own. This includes giving their work to another student to be copied, giving someone answers to exam questions during the exam, taking an exam and discussing its contents with students who will be taking the same exam, or giving or selling a term paper to another student.

3.Misrepresentation. Students misrepresent their work by handing in the work of someone else. The following are examples: purchasing a paper from a term paper service; reproducing another person's paper (even with modifications) and submitting it as their own; having another student do their computer program or having someone else take their exam.

4.Bribery. Offering money or any item or service to a faculty member or any other person to gain academic advantage for yourself or another is dishonest.

5.Plagiarism. Unacknowledged use of the information, ideas, or phrasing of other writers is an offense comparable with theft and fraud, and it is so recognized by the copyright and patent laws. Literary offenses of this kind are known as plagiarism. Plagiarism occurs when they do not credit the sources from which they borrow ideas, whether these ideas are reproduced exactly or summarized. The method of documentation will differ depending on whether the sources are written, oral, or visual. Ethically, communicators are responsible for providing accurate, detailed information about their sources. Practically, audiences need this information to comprehend and evaluate a message's content.

A student found responsible for academic dishonesty or academic misconduct is therefore subject to appropriate academic penalty; to be determined by the instructor of the course, as well as sanctions under the university Student Disciplinary Regulations. If an instructor believes that a student has behaved dishonestly in a course, the following steps are to be followed is listed in full at the following UI website: http://www.uidaho.edu/class/english/plagiarismpolicies 


\section{References}

Bell, R. (2016). The continuing search to find a more effective and less intimidating way to teach research methods in higher education. Innovations in Teaching and Education International, 53(3), 285-295.

Brierton, S., Wilson, E., Kistler, M., Flowers, J., \& Jones D. (2016). A comparison of higher order thinking skills demonstrated in synchronous and asynchronous online college discussion posts. NACTA Journal, 60(1), 14-21.

Cho, M. \& Tobias, S. (2016). Should instructors require discussion in online courses? Effects of online discussion on community of inquiry, learner time, satisfaction, and achievement. International Review of research in Open and Distributed Learning, 17(2), 124-140.

Friedlander, C. (2013). What is a Master Class? Carnegie Hall Weill Music Institute. Retrieved from: http://musicalexchange.carnegiehall.org/group/voice/forum/topics/what-is-a-master-class

Vuopala, E., Hyvönen, P., \& Järvelä, S. (2016). Interaction forms in successful collaborative learning in virtual learning environments. Active Learning in Higher Education, 17(1), 25-38.

Watts, L. (2016). Synchronous and asynchronous communication in distance learning: A review of literature. The Quarterly Review of Distance Education, 17(1), 23-32.

\section{Biographies}

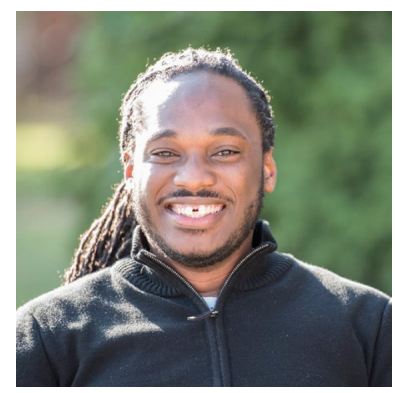

Dr. Sydney Freeman, Jr. is associate professor of Adult, Organizational Learning, and Leadership at the University of Idaho. He is a former National Holmes Scholar, a certified faculty developer through the Learning Resources Network, and an affiliate of the University of Pennsylvania's Center for Minority Serving Institutions. He currently teaches graduate courses in intermediate and advanced qualitative research. Dr. Freeman has published numerous journal articles and is the lead editor (with Linda Serra Hagedorn, Lester F. Goodchild, and Dianne A. Wright) of Advancing Higher Education as a Field of Study: In Quest of Doctoral Degree Guidelines (Stylus Publishing, 2014) which received the 2015 Auburn University Graduate School "Book of the Year" Award. He is also on the Board of Directors of the American Association of University Administrators and was honored with the "2015 Emergent Leader of the Year" award by the same professional society. He serves on multiple academic journal editorial and review boards, including serving as managing editor of the Journal of HBCU Research + Culture. He is also the founder and editor-in-chief of The Journal for the Study of Postsecondary and Tertiary Education.

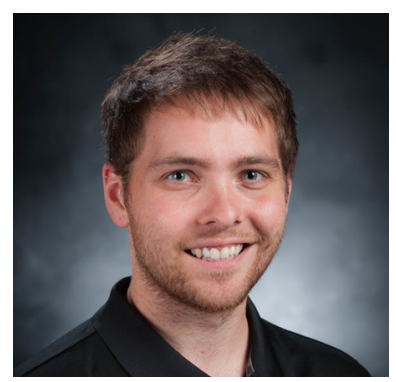

Mr. Steven Bird is a graduate student within the of Adult, Organizational Learning, and Leadership at the University of Idaho. 